\title{
Antioxidant and the Efficacy of Sophora secundiflora and Methoxyisoflavones in the Immune Function of Pigeons Vaccinated against Paramyxovirus Serotype-1
}

\author{
Howaida Ibrahim Abd-Alla1, , Magda Tohamy Ibrahim², Hanan Anwar Aly Taie ${ }^{3}$, Marwa Abas Hasan4, Nagwa \\ M. M. Shalaby'
}

Howaida Ibrahim Abd-Alla ${ }^{1, *}$, Magda Tohamy Ibrahim², Hanan Anwar Aly Taie 3 , Marwa Abas Hasan ${ }^{4}$, Nagwa M. M. Shalaby ${ }^{1}$

'Department of Chemistry of Natural Compounds, National Research Centre, El-Bohouth Street, National Research Centre, Giza-Dokki 12622, EGYPT.

2Pharmacognosy Department, Faculty of Pharmacy, Sinai University, Kantara Branch, EGYPT.

${ }^{3}$ Plant Biochemistry Department, National Research Centre, Giza-Dokki 12622, EGYPT. ${ }^{4} \mathrm{Bab}$ El-Shaariya University Hospital, Cairo, EGYPT.

\section{Correspondence}

\section{Howaida I. Abd-Alla}

Department of Chemistry of Natural

Compounds, National Research Centre, ElBohouth Street, National Research Centre,

Giza-Dokki 12622, EGYPT

Phone no.: (+2) 01001455481

E-mail: howaida_nrc@yahoo.com

History

- Submission Date: 28-06-2020;

- Review completed: 03-08-2020;

- Accepted Date: 12-08-2020

DOI : 10.5530/pj.2020.12.176

Article Available online

http://www.phcogj.com/v12/i6

\section{Copyright}

(C) 2020 Phcogj.Com. This is an open access article distributed under the terms of the Creative Commons Attribution 4.0 International license.

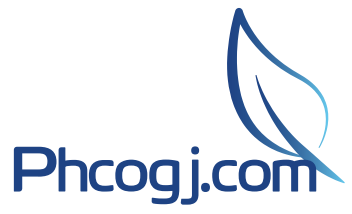

\begin{abstract}
Objective: The present work investigated the effect of oral administration of hydroalcoholic (70\% aqueous ethanol) extract (TeE) of Sophora secundiflora leaves and its organic fractions $n$-hexane (HeE), ethyl acetate (EaE) and $n$-butanol (BuE) and major isolated methoxyisoflavones $\mathbf{1}$ and $\mathbf{2}$, on the cellular and humoral immune responses to live attenuated avian paramyxovirus-1 (APMV-1) vaccines in pigeons. Methods: The structures of six isolated compounds were elucidated on the basis of chromatographic, chemical, and spectroscopic methods. The samples antioxidative and radical scavenging capabilities of 2,2-diphenyl-1-picrylhydrazyl (DPPH), 2,2'-azinobis-3-ethylbenzothiazoline-6-sulfonic acid (ABTS) radical cation and ferric reducing power were determined. Total phenolic, tannin and flavonoid contents of EaE extract were evaluated. Results: Six compounds were isolated. Three were the methoxyisoflavones57-dihydroxy-4'-methoxyisoflavone (1), 7-hydroxy-4'methoxyisoflavone (2), 5,4'-dihydroxy-7methoxy-isoflavone (3), along with isorhamnetin (4) and two quercetin derivatives quercetin 3-glucoside (5) and quercetin 3-rutinoside (6) were isolated. The hydroalcoholic extract, fractions and 4'-methoxyisoflavones showed radical scavenging effect in the order of $\mathrm{EaE}$ $>\mathrm{TeE}>\mathrm{BuE}>$ compound $\mathbf{1}>$ compound $\mathbf{2}>\mathrm{HeE}$. Stimulation of both sero-responses was observed, especially this of EaE. The results showed an increase of macrophage cells, lymphocyte and antibody titers in blood. Conclusion: The presence of 5-hydroxyl group at A-ring may be important to show the immunostimulant and antioxidant activity of compound $\mathbf{1} \mathrm{vs}$ compound $\mathbf{2}$. The present results showed the potential abilities of EaE as antioxidant and immunomodulator agent and these would impart healthy economic benefits in vaccinated birds.
\end{abstract}

Key words: Sophora secundiflora, Antiradical effect, Immune, Isoflavones, Paramyxovirus, Pigeons.

\section{INTRODUCTION}

Isoflavonoids are large subgroup of flavonoids and one of the major plant secondary metabolites that mediate diverse biological activities and potential health benefits. ${ }^{1,2}$ Isoflavones are receiving growing attention and the focus of research has been on them to promote host immune functions by augmenting cellular and humoral type. ${ }^{3,4}$ This encourages many authors to study the plant containing isoflavones such as Sophora species. ${ }^{2}$ Sophora species belongs to the family Fabaceae, contains about 52 species that are widely distributed in temperate regions. This genus is currently used as a traditional medicine for preventing a variety of ailments e.g. for dephlogistication and detoxication, and in infectious diseases ${ }^{2}$ and some species are administered orally in classical medicinal treatises of ancient China. ${ }^{5}$

Genus of Sophora is endowed with diverse bioactive molecules, such as chromones, pterocarpans, flavonoids, polysaccharides, and alkaloids. ${ }^{2}$ Oxymatrine, extracted from $S$. alopecuraides was reported as a strong immune-modulator has anti- hepatitis B virus immunomodulatory effect. ${ }^{6}$ It influences signaling transduction of toll-like receptor 9 (TLR9) and improve the efficacy of immune response of the TLR9 ligand against chronic hepatitis B by a synergistic effect. In immune-compromised mice using dexamethasone, the polysaccharide of S. subprosrate has showed immunomodulatory effect on the production of cytokines and splenic lymphocyte proliferation. ${ }^{7}$

Our present study describes the isolation and structural elucidation of isoflavones. These classes of compounds were reported to affect immune functions. ${ }^{8}$ Isoflavones are hemostatic constituents offer immunologic benefits and are known to exert pseudohormonal activity and may be used in estrogen replacement therapy. ${ }^{9}$ Isoflavones genistein and 2'-hydroxygenistein, isolated from S. alopecuroids, are known act as phytoestrogens and were reported to stimulate various aspects of immune function. ${ }^{10}$ The injection of isoflavone genistein in ovariectomized juvenile micemay be lead to affect both sero responses of immunity through either estrogen receptor (ER)-or non-ER-mediated pathways. ${ }^{9}$ Other

Cite this article: Abd-Alla HI, Ibrahim MT, Taie HAA, Hasan MA, Shalaby NMM. Antioxidant and the Efficacy of Sophora secundiflora and Methoxyisoflavones in the Immune Function of Pigeons Vaccinated against Paramyxovirus Serotype-1. Pharmacogn J. 2020;12(6):1276-88. 
isoflavone 5,7-dihydroxy-4'-methoxyisoflavone was reported to downregulate the expression of matrix metalloproteinases and upregulate tissue inhibitor of metalloproteinase- 1 at both the mRNA and protein levels in interleukin (IL)- $1 \beta$ induced rabbit chondrocytes. ${ }^{11}$

In view of the wide continued interest in the biological activity of this important genus, one of the important sources of isoflavonoids, the current study reports, herein, on the antioxidant and immunomodulatory activities of S. secundiflora species grown in Egypt on immune response in pigeons vaccinated against paramyxovirus serotype-1 (APMV-1). APMV is a virus able to infect all orders of avian species. ${ }^{12}$ In Egypt, a high mortality and morbidity was associated with the virulent strains of this virus and has a devastating effect on the poultry industry. ${ }^{13}$ The potential role of Egyptian pigeons in the transmission and evolution dynamics of APMV-1 was also suggested. ${ }^{13}$

\section{MATERIALS AND METHODS}

\section{Plant material}

Leaves of Sophora secundiflora (Ortega) Lag. ex DC. were collected from fruited trees cultivated in El-Orman Botanical Garden (OBG), Giza, Egypt. Authentication of the plant was established by Treas Labib, Herbarium Section, OBG. A voucher specimen was kept in the Department of Chemistry of Natural Compounds, National Research Centre (Egypt)

\section{Pigeons}

The birds were purchased from local market in Fayoum, Egypt. Pigeons were reared with the history of parent unvaccinated to paramyxovirus vaccine might be at day $18-22$. The birds were housed in self-contained isolation units that were ventilated under negative pressure with inlet and exhaust high efficiency particulate air (HEPA)-filtered air and maintained under continuous lighting. Feed and water were provided with ad libitum access. Birds were cared for in accordance to Central Laboratory for Evaluation of Veterinary Biologics (CLEVB) Institutional Animal Care and Use Committee approved animal use protocol.

\section{Vaccine}

Avian paramyxovirus serotype-1 (APMV-1) vaccine with a titer of $10^{6.5} \mathrm{EID}_{50} / \mathrm{mL}$ (embryo infective dose) was used for vaccination of the experimental birds via drinking water. Hemagglutination inhibition (HI) assays were used to quantify antibody responses to virus infection as previously described. ${ }^{14}$ The vaccine was tittered by measuring the hemagglutinating activity using a microplate HA test.

\section{Virus titration}

Virulent strains of APMV-1 $\left(10^{7} \mathrm{EID}_{50} / \mathrm{mL}\right)$ obtained from the bank of strains of CLEVB, Abbassia, Egypt as used as challenging virus.

\section{Phytochemical study}

\section{General experimental procedures}

The NMR spectra were recorded at $400\left({ }^{1} \mathrm{H}\right)$ and $100\left({ }^{13} \mathrm{C}\right)$ MHzon Bruker High Performance Digital FT-NMR 400 Avance III spectrometer using deuterated DMSO as solvent. The chemical shifts $(\delta)$ are reported in parts per million (ppm) and coupling constants $(J)$ in Hz. The UV-analyses of the pure samples were recorded, separately, as $\mathrm{MeOH}$ solutions and with different diagnostic UV shift reagents on a UV-visible spectrophotometer: Shimadzu UV 240 (P/N 240-5800). Sephadex LH-20 (Pharmacia, Uppsala, Sweden) and silica gel (Si) 60 mesh of 230-400 and 60-120 (E. Merck, Darmstadt, Germany) were used for column chromatography. Pre-coated silica gel plates (Kieselgel $60 \mathrm{~F} 254,0.25 \mathrm{~mm}$ ) were used for thin layer chromatography (TLC) analyses. Folin-Ciocalteu reagent, sodium carbonate, glucose and aluminum chloride were purchased from Merck Company (Darmstadt, Germany). 2,2-Diphenyl-2-picrylhydrazyl (DPPH), 2,2'-azinobis-3ethylbenzothiazoline-6-sulfonic acid (ABTS), potassium ferricyanide, and ferric chloride $\left(\mathrm{FeCl}_{3}\right)$ were purchased from Sigma Chemical Co., Ltd (St. Louis, MO, USA). All chemicals in the present study are of analytical grade. For paper chromatography, Whatman No. 1 paper sheets (Whatman Ltd., Maid stone, England) were used. The visualization of spots was carried out by spraying with the spray reagentR: $\mathrm{AlCl}_{3}$ (1\% in ethanol) were used to visualize the compounds. Solvent systems $\mathrm{S}_{1}\left[n-\mathrm{BuOH} / \mathrm{HOAc} / \mathrm{H}_{2} \mathrm{O}\left(4: 1: 5, \mathrm{v} / \mathrm{v} / \mathrm{v}\right.\right.$, top layer)], $\mathrm{S}_{2}$ (15\% aqueous $\mathrm{HOAc}$ ) and $\mathrm{S}_{3}$ [EtOAc/ $\left.\mathrm{MeOH} / \mathrm{H}_{2} \mathrm{O}(100: 13.5: 10, \mathrm{v} / \mathrm{v} / \mathrm{v})\right]$, $\mathrm{S}_{4}\left[\mathrm{EtOAc} / \mathrm{HCOOH} / \mathrm{CH}_{3} \mathrm{COOH} / \mathrm{H}_{2} \mathrm{O}(100: 11: 11: 27, \mathrm{v} / \mathrm{v} / \mathrm{v} / \mathrm{v})\right]$ and $\mathrm{S}_{5}$ $\left[n-\mathrm{BuOH} / \mathrm{C}_{3} \mathrm{H}_{8} \mathrm{O} / \mathrm{H}_{2} \mathrm{O}(4: 1: 5, \mathrm{v} / \mathrm{v} / \mathrm{v}\right.$, top layer)] were used.

\section{Extraction and isolation}

The air-dried $\left(35^{\circ} \mathrm{C}, 24 \mathrm{~h}\right.$ under air circulation) leaves $(1.2 \mathrm{~kg})$ were powdered. The scheme showed the extraction, fractionation and purification of $70 \%$ ethanolic extract of S. secundiflora (Ortega) Lag. ex DC leaves was illustrated in Figure 1.

Compound 1: yellowish-white crystals $(35 \mathrm{mg}) ; \mathrm{R}_{\mathrm{f}}: 0.89\left(\mathrm{~S}_{1}\right)$ and 0.30 $\left(\mathrm{S}_{2}\right)$, m.p. $210-213{ }^{\circ} \mathrm{C}$; UV $\lambda_{\text {max }}(\mathrm{nm}):(\mathrm{MeOH}): 261$ and $330(\mathrm{sh}),(+$ $\mathrm{NaOMe}): 273$ and 329, $\left(+\mathrm{AlCl}_{3}\right): 273,310(\mathrm{sh})$ and $375,\left(+\mathrm{AlCl}_{3} / \mathrm{HCl}\right)$ : 273, 310 (sh) and 373, (+ NaOAc): 272 and 326, $\left(+\mathrm{NaOAc} / \mathrm{H}_{3} \mathrm{BO}_{3}\right): 262$ and $330(\mathrm{sh}) ;{ }^{1} \mathrm{H}$ NMR (400 MHz, DMSO- $\left.d_{6}\right): \delta_{\mathrm{pmm}} 8.37(1 \mathrm{H}, \mathrm{s}, \mathrm{H}-2)$, $7.51\left(2 \mathrm{H}, \mathrm{d}, J=8.72 \mathrm{~Hz}, \mathrm{H}-2^{\prime} / 6^{\prime}\right), 7.02\left(2 \mathrm{H}, \mathrm{d}, J=8.76 \mathrm{~Hz}, \mathrm{H}-3^{\prime} / 5^{\prime}\right), 6.24$ $(1 \mathrm{H}, \mathrm{d}, J=2.04 \mathrm{~Hz}, \mathrm{H}-8), 6.40(1 \mathrm{H}, \mathrm{d}, J=2.04 \mathrm{~Hz}, \mathrm{H}-6), 3.79(3 \mathrm{H}, \mathrm{s}$, $\left.\mathrm{O}-\mathrm{CH}_{3}\right) .{ }^{13} \mathrm{C}$ NMR $\left(100 \mathrm{MHz}, \mathrm{DMSO}-d_{6}\right): \delta_{\mathrm{ppm}} 180.6(\mathrm{C}-4), 164.8(\mathrm{C}-7)$, 162.4 (C-5), 159.6 (C-4'), 158.1 (C-9), 154.8 (C-2), 130.6 (C-2'/ 6'), 123.4 (C-3), $122.4\left(\mathrm{C}-1^{\prime}\right), 114.2$ (C3'/5'), 104.9 (C-10), 99.5 (C-6), 94.2 (C-8), $55.6\left(\mathrm{O}-\mathrm{CH}_{3}\right)$.

Compound 2: yellow amorphous powder (33 mg); $\mathrm{R}_{\mathrm{f}}: 0.49\left(\mathrm{~S}_{3}\right), 0.28$ $\left(\mathrm{S}_{4}\right)$, m.p. $221^{\circ} \mathrm{C}$; UV $\lambda_{\text {max }}(\mathrm{nm}):(\mathrm{MeOH}): 248,258(\mathrm{sh})$ and $301,(+$ $\mathrm{NaOMe}): 255$ and $335(\mathrm{sh}),\left(+\mathrm{AlCl}_{3}\right): 248,261(\mathrm{sh})$ and $301,\left(+\mathrm{AlCl}_{3} /\right.$ $\mathrm{HCl}): 248,261(\mathrm{sh})$ and $302,(+\mathrm{NaOAc}): 254,313$ and 335(+NaOAcl $\left.\mathrm{H}_{3} \mathrm{BO}_{3}\right): 264$ and 303(sh). ${ }^{1} \mathrm{H}$ NMR $\left(400 \mathrm{MHz}\right.$, DMSO- $\left.d_{6}\right): \delta_{\mathrm{ppm}} 8.16$ $(1 \mathrm{H}, \mathrm{d}, J=8.8, \mathrm{H}-5), 7.99$ (1H, s, H-2),7.55 (2H, d, J= 8.8, H-2'/6'), 7.14 $(1 \mathrm{H}, \mathrm{dd}, J=2.4$ and $8.8, \mathrm{H}-6), 7.01(1 \mathrm{H}, \mathrm{d}, J=2.4, \mathrm{H}-8), 6.95(2 \mathrm{H}, \mathrm{d}, J=$ 8.8, H-3'/5'), 3.50 (3H, s, O-CH $).{ }^{13} \mathrm{C}$ NMR (100 MHz, DMSO- $\left.d_{6}\right): \delta_{\mathrm{ppm}}$ 176.8 (C-4), 171.0 (C-7), 159.7 (C-4), 157.3 (C-9), 152.9 (C-2), 130.04 (C-2'/6), 126.2 (C-5), 124.8 (C-1'), 123.8 (C-3), 118.3 (C-10), 114.5 (C6), $114.2\left(\mathrm{C}-3^{\prime} / 5^{\prime}\right), 103.04(\mathrm{C}-8), 54.2\left(\mathrm{O}-\mathrm{CH}_{3}\right)$.

Compound 3: yellow amorphous powder $(20 \mathrm{mg}) ; \mathrm{R}_{\mathrm{f}}: 0.86\left(\mathrm{~S}_{2}\right)$ and 0.31 $\left(\mathrm{S}_{2}\right)$, m.p. $240-242{ }^{\circ} \mathrm{C}$. UV $\lambda_{\max }(\mathrm{nm}):(\mathrm{MeOH}): 263$ and 325 (sh), (+ $\mathrm{NaOMe}): 272$ and $353,\left(+\mathrm{AlCl}_{3}\right): 273,309(\mathrm{sh})$ and $374,\left(+\mathrm{AlCl}_{3} / \mathrm{HCl}\right)$ : $279,310(\mathrm{sh})$ and $370,(+\mathrm{NaOAc}): 262$ and $330,\left(+\mathrm{NaOAc} / \mathrm{H}_{3} \mathrm{BO}_{3}\right): 262$ and 332 (sh). ${ }^{1} \mathrm{H}$ NMR (400 MHz, DMSO- $\left.d_{6}\right): \delta_{\mathrm{ppm}} 8.17(1 \mathrm{H}, \mathrm{s}, \mathrm{H}-2), 7.34$ $\left(2 \mathrm{H}, \mathrm{d}, J=8.56 \mathrm{~Hz}, \mathrm{H}-2^{\prime} / 6^{\prime}\right), 6.80\left(2 \mathrm{H}, \mathrm{d}, J=8.56 \mathrm{~Hz}, \mathrm{H}-3^{\prime} / 5^{\prime}\right), 6.51(1 \mathrm{H}$, $\mathrm{d}, J=2.16 \mathrm{~Hz}, \mathrm{H}-6), 6.32(1 \mathrm{H}, \mathrm{d}, J=2.16 \mathrm{~Hz}, \mathrm{H}-8), 3.81\left(3 \mathrm{H}, \mathrm{s}, \mathrm{O}-\mathrm{CH}_{3}\right)$. ${ }^{13} \mathrm{C}$ NMR (100 MHz, DMSO- $\left.d_{6}\right): \delta_{\mathrm{ppm}} 180.1$ (C-4), 165.0 (C-7),161.4 (C5), $157.4\left(\mathrm{C}-4^{\prime}\right), 157.0$ (C-9), 153.4 (C-2), 129.7 (C-2'/ 6'), 122.6 (C-3), $121.0\left(\mathrm{C}-1^{\prime}\right), 114.5\left(\mathrm{C}-3^{\prime} / 5^{\prime}\right), 105.1$ (C-10), 97.4 (C-6), 91.6 (C-8), 55.06 $\left(\mathrm{O}-\mathrm{CH}_{3}\right)$.

Compound 4: yellow microcrystalline powder, $20 \mathrm{mg} ; \mathrm{R}_{\mathrm{f}} ; 0.75\left(\mathrm{~S}_{1}\right) ; 0.28$ $\left(\mathrm{S}_{2}\right)$, m.p. $294-296^{\circ} \mathrm{C} ;{ }^{1} \mathrm{H}$ NMR $\left(400 \mathrm{MHz}\right.$, DMSO- $\left.d_{6}\right), \delta_{\mathrm{ppm}} 7.48(1 \mathrm{H}, \mathrm{d}$, $\left.J=2.0 \mathrm{~Hz}, \mathrm{H}-2^{\prime}\right), 7.32\left(1 \mathrm{H}, \mathrm{dd}, J=8.4 \mathrm{~Hz}, 2.0, \mathrm{H}-6^{\prime}\right), 6.78^{\mathrm{ppm}}(1 \mathrm{H}, \mathrm{d}, J=8.4$ $\left.\mathrm{Hz}, \mathrm{H}-5^{\prime}\right), 6.25(1 \mathrm{H}, \mathrm{d}, J=2.0 \mathrm{~Hz}, \mathrm{H}-8), 6.23(1 \mathrm{H}, \mathrm{d}, J=2.0 \mathrm{~Hz}, \mathrm{H}-6)$, $3.71\left(3 \mathrm{H}, s, \mathrm{O}-\mathrm{CH}_{3}\right) ;{ }^{13} \mathrm{C}$ NMR $\left(100 \mathrm{MHz}\right.$, DMSO- $\left.d_{6}\right), \delta_{\mathrm{ppm}} 176.4(\mathrm{C}-4)$, 167.4 (C-7), 164.8 (C-5), 161.3 (C-9), 156.8 (C-2), 148.4 (C-4'), 147.4 (C-3'), 145.7 (C-5'), 136.3 (C-3), $147.4\left(\mathrm{C}-3^{\prime}\right), 120.6$ (C-1'), 116.3 (C-6'),

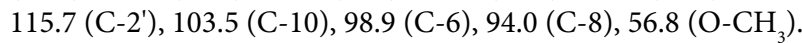

Compound 5: dark yellow amorphous powder, $20 \mathrm{mg} ; \mathrm{R}_{\mathrm{f}}: 0.56\left(\mathrm{~S}_{1}\right)$ and $0.36\left(\mathrm{~S}_{2}\right)$; m.p. $219-221^{\circ} \mathrm{C}$; $\mathrm{UV} \lambda_{\max }(\mathrm{nm}),(\mathrm{MeOH}): 258$ and 354 ; 
Air-dried powdered leaves of S. secundiflora (Ortega) Lag. ex DC (1.2 Kg)

n-Hexane extract $(24.9 \mathrm{~g})$ (biological activity)
A) Extraction with $70 \%$ EtOH by successive extraction until exhaustion.

B) Evaporation of EtOH under reduced pressure $\left(45^{\circ} \mathrm{C}\right)$.

Fractionation with $n$-hexane $(5 \mathrm{X} 0.5 \mathrm{~L})$, ethyl acetate $(4 \mathrm{X} 0.5 \mathrm{~L})$ and $n$ butanol (4X 0.5 L) successively.

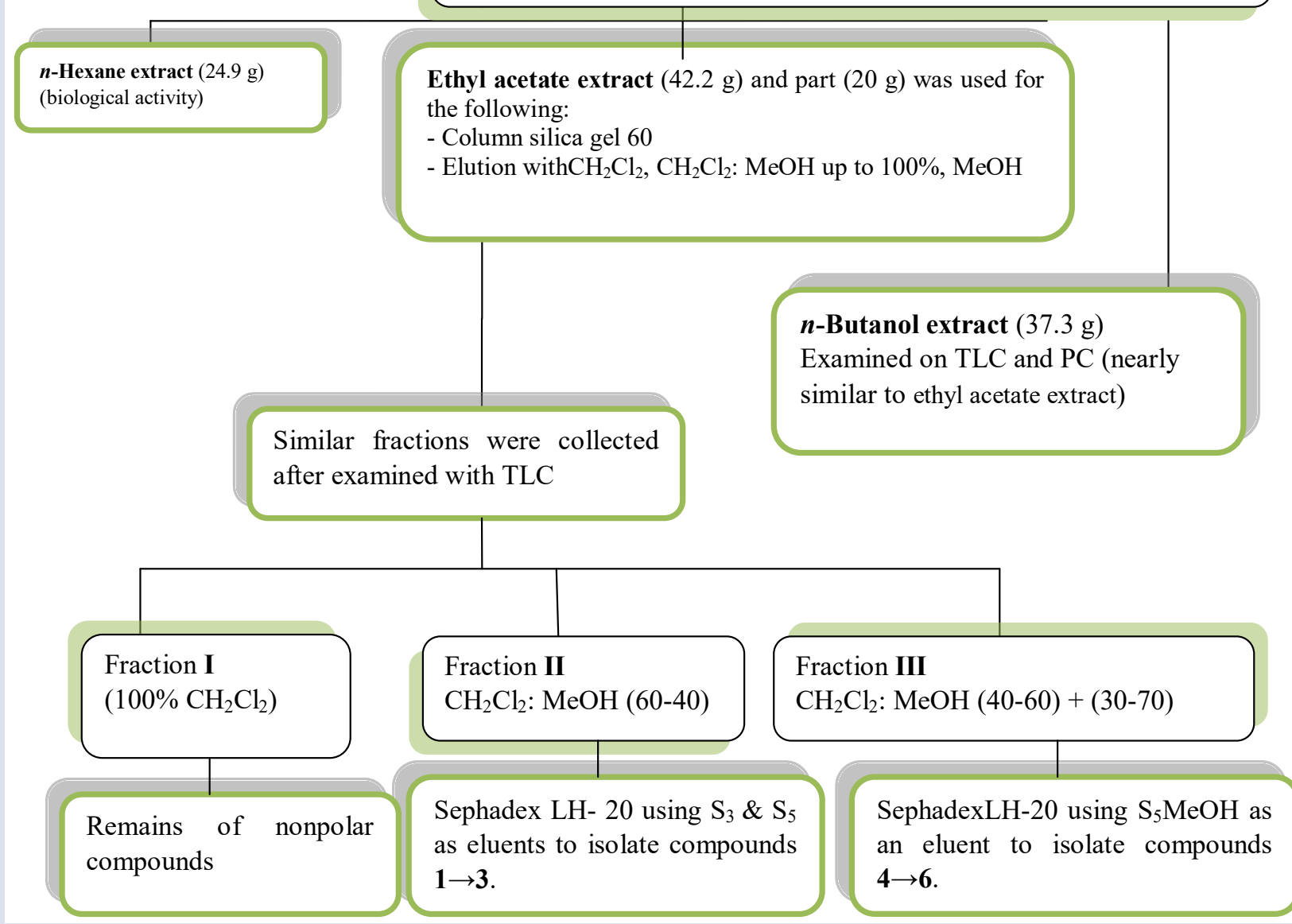

Figure 1: Extraction, fractionation and purification of $70 \%$ ethanolic extract of S. secundiflora (Ortega) Lag. ex DC leaves.

(+NaOMe):273, 325 and 409; (+NaOAc): 273, 321 and 373; (+NaOAcl $\left.\mathrm{H}_{3} \mathrm{BO}_{3}\right): 263$ and 377; $\left(+\mathrm{AlCl}_{3}\right): 274,302$ and 427; $\left(\mathrm{AlCl}_{3} / \mathrm{HCl}\right): 270$, 302, 356 and 402; ${ }^{1} \mathrm{H}$ NMR (400 MHz, DMSO- $d_{6}$ ), $\delta_{\mathrm{ppm}}$ Aglycone: 12.64 $(1 \mathrm{H}, \mathrm{s}, \mathrm{H}-$ bond $\mathrm{OH}-5), 7.60(1 \mathrm{H}, \mathrm{dd}, \mathrm{H}-6$ ' hidden by $\mathrm{H}-2 "), 7.58(1 \mathrm{H}$, d, $\left.J=6.2 \mathrm{~Hz}, \mathrm{H}-2^{\prime}\right), 6.85\left(1 \mathrm{H}, \mathrm{d}, J=9 \mathrm{~Hz}, \mathrm{H}-5^{\prime}\right), 6.39(1 \mathrm{H}, \mathrm{d}, J=1.6$ $\mathrm{Hz}, \mathrm{H}-8), 6.19(1 \mathrm{H}, \mathrm{d}, J=1.6 \mathrm{~Hz}, \mathrm{H}-6), 5.47(1 \mathrm{H}, \mathrm{d}, J=6.6 \mathrm{~Hz}, \mathrm{H}-1 ")$, 3.59-3.08 (m, rest of glucose protons); ${ }^{13} \mathrm{C}$ NMR (100 MHz, DMSO- $\left.d_{6}\right)$, $\delta_{\mathrm{ppm}} 177.9(\mathrm{C}-4), 164.9$ (C-7), 161.7 (C-5), 156.8 (C-2), 156.6 (C-9), 148.5 (C-4'), 145.3 (C-3'), 133.7 (C-3), 122.1 (C-6'), 121.6 (C-1'), 116.6 (C-5'), 115.7 (C-2'), 104.4 (C-10), 101.3 (C-1"), 99.2 (C -6), 94.0 (C8),78.6 (C-5"),77.9 (C-3"), 74.5 (C-2"), 70.4 (C-4"), 61.4 (C-6").

Compound 6: yellow crystals, 18 mg; $\mathrm{R}_{\mathrm{f}}: 0.46\left(\mathrm{~S}_{1}\right) ; 0.60\left(\mathrm{~S}_{2}\right)$, m.p. 189$191{ }^{\circ} \mathrm{C} ;{ }^{1} \mathrm{H}$ NMR (400 MHz, DMSO- $\left.d_{6}\right): \delta_{\mathrm{ppm}}$ aglycone: $12.59(1 \mathrm{H}, \mathrm{s}$,
5-OH), $7.55\left(1 \mathrm{H}, \mathrm{dd}, J=2.5,8.5 \mathrm{~Hz}, \mathrm{H}-2^{\prime}\right), 7.53\left(1 \mathrm{H}, \mathrm{d}, J=2.5 \mathrm{~Hz}, \mathrm{H}-6^{\prime}\right)$, $6.84\left(1 \mathrm{H}, \mathrm{d}, J=8.5 \mathrm{~Hz}, \mathrm{H}-5^{\prime}\right), 6.37(1 \mathrm{H}, \mathrm{d}, J=1.2 \mathrm{~Hz}, \mathrm{H}-8), 6.18(1 \mathrm{H}$, d, $J=1.2 \mathrm{~Hz}, \mathrm{H}-6)$, sugar: $5.34(1 \mathrm{H}, \mathrm{d}, J=7.5 \mathrm{~Hz}, \mathrm{H}-1 "), 4.38(1 \mathrm{H}, \mathrm{s}$, H-1"'), 3.07-3.72 (m, rest of sugar protons), $0.99(3 \mathrm{H}, \mathrm{d}, J=6.0 \mathrm{~Hz}$, Rha$\left.\mathrm{CH}_{3}\right) ;{ }^{13} \mathrm{C}$ NMR (100 MHz, DMSO-d $)$ : $\delta_{\mathrm{ppm}} 178.1$ (C-4), 164.7 (C-7), 161.9 (C-5), 157.3 (C-2), 157.1 (C-9), 149.1 (C-4'), 145.4 (C-3'), 134.0 (C-3),122.3 (C-1'),121.9 (C-6'),117.0 (C-5'), 115.9 (C-2'),104.7 (C-10), 101.9 (C-1"), 101.4 (C-1"'), 99.4 (C-6), 94.3 (C-8), 77.2 (C-3"), 76.6 (C5"), 74.8 (C-2"), 72.6 (C-4"'), 71.3 (C-2"'), 71.1 (C-3"'), 70.7 (C-4"), 68.9 (C-5"'), 67.7 (C-6"), $18.4\left(\right.$ Rha- $\left.\mathrm{CH}_{3}\right)$.

\section{Quantitative determination of total phenolics content}

Total phenolic content of $S$. secundiflora (Ortega) Lag. ex leaves extract was estimated by the Folin-Ciocalteu method using gallic acid as 
standard. ${ }^{15}$ Aliquots of the extract were taken in a test tube and made up to the volume of $1 \mathrm{~mL}$ with distilled water. The distilled water itself was used as blank. Then $0.5 \mathrm{~mL}$ of Folin-Ciocalteu reagent (1:1 with water) and $2.5 \mathrm{~mL}$ of sodium carbonate solution (20\%) were added sequentially in each tube. Soon after vortex the reaction mixture, the tubes were placed in the dark for $40 \mathrm{~min}$ and the absorbance was recorded at 725 $\mathrm{nm}$ against the reagent blank. Total polyphenol contents were expressed as mg gallic acid equivalents (GAE)/g dry weight, calculated from a standard curve prepared with $00-100 \mathrm{mg} / \mathrm{L}$ gallic acid.

\section{Quantitative determination of total flavonoids content}

Total flavonoid content of ethanol extract was estimated by a colorimetric assay according to Ordonez et al. ${ }^{16}$ To $0.5 \mathrm{~mL}$ of dry leaves extract, $0.5 \mathrm{~mL}$ of $2 \% \mathrm{AlCl}_{3}$ ethanol solution was added. After $1 \mathrm{~h}$ at room temperature, filtered, then the absorbance was measured at 420 $\mathrm{nm}$. Total flavonoid content was expressed as mg quercetin equivalents $(\mathrm{QE}) / \mathrm{g}$ dry weight, calculated from a standard curve prepared with $0-500 \mu \mathrm{g} / \mathrm{mL}$ quercetin.

\section{Quantitative determination of total tannins content}

Total tannin content of ethanol extract was determined according to modification to the Folin-Ciocalteu method using polyvinyl polypyrrolidone (PVPP) to separate tannin phenols from non-tannin phenols. About $100 \mathrm{mg}$ of PVPP was added to $1 \mathrm{~mL}$ sample extracts diluted with $1 \mathrm{~mL}$ water and left $15 \mathrm{~min}$ at $4^{\circ} \mathrm{C}$. After centrifugation, PVPP forms a precipitate with tannins, and the supernatant has only simple phenols. Simple phenols were determined using the FolinCiocalteu reagent. The difference between total and simple phenol values represents the total tannin content, expressed as mg GAE/g dry weight.

\section{Role of S. secundiflora on immune responses in vaccinated pigeons}

A pilot experiment was carried out to choose the suitable dose which neither caused degeneration nor necrosis in livers and kidneys. Samples of $0.25,0.5$ and $1 \mathrm{mg} / \mathrm{kg}$ body weight (b.w.) of TeE, HeE, EaE, and $\mathrm{BuE}$ and compounds 1 and 2 were given orally to pigeons, separately. It was found that the selected dose for studying the immunomodulatory activity was $0.25 \mathrm{mg} / \mathrm{kg}$ b.w. Pigeons were reared and kept in isolators under complete hygienic measure and divided into 8 groups each of 45 pigeons. The first non-treated non-vaccinated group was considered as control. The second group was vaccinated at the $7^{\text {th }}$ day with living attenuated APMV-1vaccine. The remaining six groups received 0.25 $\mathrm{mg} / \mathrm{kg}$ b.w. of each extract and compounds $\mathbf{1}$ and $\mathbf{2}$ orally daily from the $2^{\text {nd }}$ to $6^{\text {th }}$ day of life. Then they were vaccinated at the $7^{\text {th }}$ day with living attenuated APMV-1 vaccines via drinking water. Twenty random blood samples were collected from each group at 3, 7, 10, 14, 21, 28, and 35 dose post vaccination (DPV).

\section{Immunomodulatory activity}

\section{Humoral immune response}

Ten of the previously mentioned 20 random blood samples were used for estimation of humoral immune response after serum separation using the hemagglutination inhibition (HI) test. ${ }^{16}$

\section{Cell-mediated immune response}

The other ten samples were used for the evaluation of cell- mediated immune response via the following tests:

\section{Assay of lymphocyte blastogenesis}

The lymphocyte blastogenesis assay ${ }^{17}$ was carried out and evaluated using the MTT test. ${ }^{18}$ The results were expressed as Delta optical density. The change in optical densities were recorded at $\lambda_{\max } 490 \mathrm{~nm}$ by the aid of an automatic Titertek multiskan Reader model ELX 800 UV, INC, USA for reading ELISA plated.

\section{Macrophage migration index}

Macrophage activity was preceded and the phagocytic index ${ }^{19}$ was determined as follows: phagocytic percentage $=$ total no. of phagocytes which ingest more than 2 Candida / total no. of phagocytes which ingest Candida.

\section{Avian paramyxovirus serotype-1 (APMV-1) challenge test}

The humoral and cellular immune response were confirmed by the APMV-1 challenge test and were proceeded by choosing 15 pigeons randomly from each group at 3,14 , and $35 \mathrm{DPV}$ and subjected to the challenge test with $0.5 \mathrm{~mL}$ of APMV-1 strain $\left(10^{6} \mathrm{EID}_{50} / \mathrm{mL}\right)$. The chickens were observed for $10 \mathrm{DPV}$ or any symptoms of disease. Pigeons died within this period were collected and subjected to detailed post mortem examination.

\section{Investigation of in vitro antioxidants activities}

\section{DPPH free radical scavenging assay}

The free-radical scavenging activity using DPPH reagent was determined according to Brand-Williams et al. ${ }^{20}$ The extracts and isolated compounds of $S$. secundiflora were soluble with $85: 15 \mathrm{v} / \mathrm{v}$ methanol: water. To $0.5 \mathrm{~mL}$ of the extract sample $1.0 \mathrm{~mL}$ of freshly prepared ethanolic DPPH solution $\left(20 \mu \mathrm{g} / \mathrm{mL}^{-1}\right)$ was added and stirred. The decolorizing process was recorded after $5 \mathrm{~min}$ of reaction at 517 $\mathrm{nm}$ and compared with a blank control. All samples were analyzed in triplicate. The ability to scavenge the DPPH radical was calculated using the following equation:

DPPH scavenging activity $(\%)=[$ control absorbance - sample absorbance) / control absorbance] $\times 100$.

\section{ABTS radical scavenging activity}

ABTS radical scavenging activity was measured by the ABTS cation decolorization assay as described by Rice-Evans et al. ${ }^{21}$ with some modifications. The stock solutions included $7 \mathrm{mM}$ ABTS solutions and $2.4 \mathrm{mM}$ potassium persulfate solution. The working solution was then prepared by mixing the two stock solutions in equal quantities and allowing them to react for $12 \mathrm{~h}$ at room temperature in the dark. The solution was then diluted by mixing $1 \mathrm{~mL}$ ABTS radical solution with $60 \mathrm{~mL}$ methanol to obtain an absorbance of $0.706 \pm 0.001$ units at $734 \mathrm{~nm}$ using the spectrophotometer. ABTS radical solution was freshly prepared for each assay. The extracts and isolated compound of S. secundiflora $(0.5 \mathrm{~mL})$ was allowed to react with $2.5 \mathrm{~mL}$ of the ABTS reagent and the absorbance was taken at $734 \mathrm{~nm}$ after 7 min using the spectrophotometer. The ABTS radical cation decolorization assay capacity of the extract and percentage inhibition calculated as ABTS radical scavenging activity.

$\operatorname{ABTS}(\%)=[($ Abs. control - Abs. sample $)] /$ (Abs. control) $] \times 100$

Where Abs. controls the absorbance of ABTS radical cation methanol; Abs. sample is the absorbance of ABTS radical cation sample extract.

\section{Reducing power assay}

The method of Oyaizu and $\mathrm{Jpn}^{22}$ was used to assess the reducing power of the extracts and isolated compounds of Sophora secundiflora. From each extract $(0.5 \mathrm{~mL})$ was added to phosphate buffer $(2.5 \mathrm{~mL}, 0.2 \mathrm{M}$, $\mathrm{pH}$ 6.6) and $1 \%$ potassium ferricyanide $(2.5 \mathrm{~mL})$. The mixture was incubated at $50{ }^{\circ} \mathrm{C}$ for $20 \mathrm{~min}$. Aliquots of trichloroacetic acid $(2.5 \mathrm{~mL}$, $10 \%)$ were added to the mixture, which was then centrifuged at 1000 $\mathrm{rpm}$ for $10 \mathrm{~min}$. The upper layer of solution $(2.5 \mathrm{~mL})$ was mixed with distilled water $(2.5 \mathrm{~mL})$ and a freshly prepared $\mathrm{FeCl}_{3}$ solution $(0.5 \mathrm{~mL}$ $0.1 \%)$. The intensity of the blue-green color was measured at $700 \mathrm{~nm}$. 
In this assay, the yellow color of the test solution changes to be green depending on the reducing power of test specimen. The presence of reductants in the solution causes the reduction of the ferric/ferricyanide complex to the ferrous form. Therefore, ferrous can be monitored by the measurement of the absorbance at $700 \mathrm{~nm}$. Increased absorbance of their action mixture indicated increased reducing power.

\section{RESULTS}

\section{Phytochemical investigation}

\section{Identification of compounds}

Chromatographic fractionation and purification of the EaE extract of the leaves of S. secondi flora on different columns of Si gel and Sephadex LH-20 afforded six compounds 1-6 (Figure 2). Three flavonoids, previously not isolated from this plant, were the isorhamnetin $\mathbf{4}$ and the two quercetin derivatives quercetin $3-O-\beta-\mathrm{D}-{ }^{4} \mathrm{C}_{1}$-glucopyranoside (isoquercitrin, 5) and quercetin-3-O- $\alpha-\mathrm{L}^{-}{ }^{1} \mathrm{C}_{4}$-rhamnopyranosyl$\left(1^{\prime \prime} \rightarrow 6 "\right)-O-\beta-D_{-}{ }^{4} \mathrm{C}_{1}$-glucopyranoside (quercetin 3-rutinoside, 6) and the 5-hydroxy-isoflavones; 4'-O-methyl genistein 1 and 5,4'-dihydroxy7-methoxy-isoflavone 3 as well as the 7-hydroxy-4'-methoxyisoflavone (4'-methoxy-daidzein) 2. Compounds 1 and $\mathbf{2}$ were previously detected in plant roots while compound $\mathbf{3}$ was in the plant stems. ${ }^{23}$

The isolated compounds were identified by UV, ${ }^{1} \mathrm{H}$ NMR and ${ }^{13} \mathrm{C}$ NMR analyses. The analytical data were in agreement with those reported in the literature. The chromatographic properties of compounds 1 - 3 suggested the characteristics of isoflavonoid. TLC of the three compounds showed them as yellow spot in visible light and purple under UV light that remained blue after exposure to ammonia vapor. The UV spectrum of these compounds $\mathbf{1}-\mathbf{3}$ in methanol exhibited two absorption maxima in the ranges 245 to 275 and 300 to 330 $\mathrm{nm}$ which are characteristics for isoflavones structure. Compound 1 showed the characteristic of absorption of 261 and 330 (sh) while compound 2 showed the characteristic of absorption of 248, 258 (sh) and $301 .{ }^{24}$ Compound 3 has $\lambda_{\max }$ at 263 and $325 \mathrm{~nm}$. Compounds 1 and 3 showed a bathochromic shift of 273, 310 (sh), 375 and 273 and 309 $\mathrm{nm}$ respectively on addition of $\mathrm{AlCl}_{3}$ and no change with $\mathrm{AlCl}_{3} / \mathrm{HCl}$ relative to methanol spectrum indicating the presence of free $5-\mathrm{OH}$ group. While compound 2 showed no bathochromic shift on addition of $\mathrm{AlCl}_{3}$ suggesting the absence of free $5-\mathrm{OH}$ group. The presence of a free 7-OH group at C-7 of compounds $\mathbf{1}$ and $\mathbf{2}$ is evidenced by a bathochromic shift in Band II, induced by NaOAc by 270, 326(sh) and 254,313 , respectively. While nothing was observed with compound 3 on addition of NaOAc that may be attributed to the substituted C-7 in ring A. ${ }^{1} \mathrm{H}$ NMR spectrum of compound $\mathbf{1}$ showed characteristic signal at $\delta_{\mathrm{H}} 8.37 \mathrm{ppm}$ indicating a proton on $\mathrm{C}-2$ which is characteristic for isoflavones, and a singlet signal at $\delta_{\mathrm{H}} 3.79 \mathrm{ppm}$ indicating one methoxy group. ${ }^{24}$ The ${ }^{1} \mathrm{H}$ NMR resonances of compound 1 showed two coupled doublets at $\delta_{\mathrm{H}} 6.40$ and $6.24 \mathrm{ppm}$ with a small coupling constant $(J=$
$2.04 \mathrm{~Hz}$ ) were characteristic of two meta-related $\mathrm{H}-6$ and $\mathrm{H}-8$ protons of ring A of an isoflavone. These chemical shifts indicate 5,7-dihydroxy substitution pattern. While compound 2 showed resonances at $\delta_{\mathrm{H}} 7.14$ $(J=8.8$ and $2.4 \mathrm{~Hz})$ and $\delta_{\mathrm{H}} 7.01(J=2.4 \mathrm{~Hz})$ which are corresponding to $\mathrm{H}-6$ and $\mathrm{H}-8$ protons in ring A respectively. The presence of signals at $\delta_{\mathrm{H}} 7.51 \mathrm{ppm}\left(J=8.72 \mathrm{~Hz}, \mathrm{H}-2^{\prime} / 6^{\prime}\right)$ and at $\delta_{\mathrm{H}} 7.02 \mathrm{ppm}(J=8.76 \mathrm{~Hz}$, $\left.\mathrm{H}-3^{\prime} / 5^{\prime}\right)$ indicating the presence of the methoxy group at C-4' in ring B of compound 1. Spectrum of compound 2 revealed characteristic patterns of isoflavone proton resonances in the aromatic region at $\delta_{\mathrm{H}} 7.55(J=8.8$ $\left.\mathrm{Hz}, \mathrm{H}-2^{\prime} / 6^{\prime}\right)$ and $\delta_{\mathrm{H}} 6.95\left(J=8.8 \mathrm{~Hz}, \mathrm{H}-3^{\prime} / 5^{\prime}\right)$ corresponding to $\mathrm{B}$ ring protons. Compound 3 exhibited one methoxy group $\delta_{\mathrm{H}} 3.81(\mathrm{~s})$, one set of meta-coupled aromatic protons $\delta_{\mathrm{H}} 6.51(\mathrm{~d}, J=2.16 \mathrm{~Hz})$ and $\delta_{\mathrm{H}} 6.32(\mathrm{~d}$, $J=2.16 \mathrm{~Hz})$, two sets of ortho-coupled aromatic protons $\delta_{\mathrm{H}} 7.34(J=8.56$ $\mathrm{Hz})$ and $\delta_{\mathrm{H}} 6.80(J=8.56 \mathrm{~Hz})$ and a non-coupled aromatic hydrogen $\delta_{\mathrm{H}}$ 8.17 (s). The low field aromatic singlet at $\delta_{\mathrm{H}} 8.17$ was assigned to $\mathrm{H}-2$ due to deshielding effects of the oxygen atom in the furan ring. These features are characteristic of a 5,4'-dihydroxyisoflavone derivative ${ }^{25}$, in addition of $\delta_{\mathrm{H}} 3.81\left(\mathrm{~s}, \mathrm{O}-\mathrm{CH}_{3}\right)$. Compound 1 showed characteristic resonance at $\delta 8.16(J=8.8, \mathrm{H}-5), \delta 7.99(s, \mathrm{H}-2)$ and $\delta 3.50(\mathrm{~s}$, $\left.\mathrm{O}-\mathrm{CH}_{3}\right) \cdot{ }^{13} \mathrm{C}$ NMR chemical shift positions of ring carbons of compound 1 and 2 were found in the range of range 94.2-180.and 103.0-176.8 ppm. Compounds1and 2 showed signals at $\delta 154.8$ and 152.9, respectively of the $\mathrm{C}-2$ characteristic of isoflavone type. In addition to the appearance of absorbance at $\delta 55.6$ and 54.2 corresponding to $\mathrm{O}-\mathrm{CH}_{3}$ at $\mathrm{C}-4$ ' was reported. ${ }^{26,2713} \mathrm{C}$ NMR spectrum of compound 3 exhibited the presence of fifteen carbons and directly proved the methoxylation on C-7 due to the appearance of the methoxy resonance at $\delta 55.1$ and the second one was the $\alpha$-downfield shift of $165.0(\Delta \sim+2 \mathrm{ppm})$ of $\mathrm{C}-7$ and $\beta$ upfield of C-6 at $97.4(\Delta \sim-2 \mathrm{ppm})$ relative to these of genistein. ${ }^{26,27}$ They were identified as 5-7-dihydroxy-4'-methoxyisoflavone (1), 7-hydroxy-4'methoxyisoflavone (2), 5,4'-dihydroxy-7-methoxy-isoflavone (3).

Compound 4 showed yellow spot and compounds 5 and $\mathbf{6}$ showed dark purple spot under long/short UV. These compoundsturned tobright yellow fluorescent with ammonia vapour or spray reagent $\mathrm{R}_{1} \cdot{ }^{1} \mathrm{H}$ NMR spectrum of compound 4 showed an ABM spin coupling system of two protons in the form of doubled at $\delta 7.48\left(\mathrm{H}-2^{\prime}\right), 7.32(\mathrm{H}-$ $\left.6^{\prime}\right)$ and one proton ortho-doubled assigned to $\mathrm{H}-5$ ' at $\delta 6.78$ conclude a 3',4'-disubstituted B-ring. Compound 5 exhibited a spin coupling system in the form of ABX for three types of protons H-2', 6' and $5^{\prime}$ of a 3',4'-dihdroxy B-ring. Additionally, 5,7-dihydroxy A-ring of compound 4 was deduced due to the two brs, one proton each, at $\delta 6.25$ and 6.23 describable to $\mathrm{H}-8$ and $\mathrm{H}-6$, respectively. While in case of compound $\mathbf{5}$, another spin coupling system was exhibited and was explained as two douplet signals of the two meta coupled protons H-6 and H-8 in a 5,7-dihydroxy A-ring. The large $J$-value $(\sim 7 \mathrm{~Hz}, \beta$-configuration $)$ and characteristic $\delta$-value (5.47 of $3-\mathrm{O}$-glucoside) of $\mathrm{H}$-1"were indicative for $O-\beta-{ }^{4} \mathrm{C}_{1}$-pyranose structure of the glucoside moiety. ${ }^{1} \mathrm{H}$ NMR spectrum of compound $\mathbf{6}$ showed a $\beta$-anomeric proton signal of inner glucoside moiety at $\delta 5.34$ and $\alpha$-anomeric proton signal at $\delta 4.38$ for

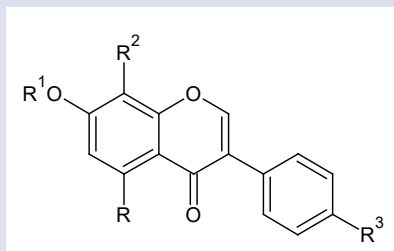

1: $\mathrm{R}=\mathrm{OH}, \mathrm{R}^{1}=\mathrm{R}^{2}=\mathrm{H}, \mathrm{R}^{3}=\mathrm{OCH}_{3}$

2: $\mathrm{R}=\mathrm{R}^{1}=\mathrm{R}^{2}=\mathrm{H}, \mathrm{R}^{3}=\mathrm{OCH}_{3}$

3: $\mathrm{R}=\mathrm{OH}, \mathrm{R}^{1}=\mathrm{CH}_{3}, \mathrm{R}^{2}=\mathrm{H}, \mathrm{R}^{3}=\mathrm{OH}$

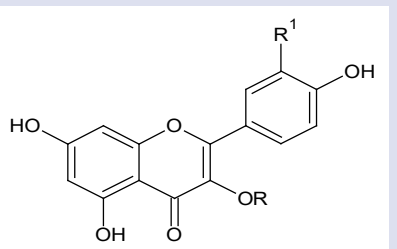

4: $\mathrm{R}=\mathrm{H}, \mathrm{R}^{1}=\mathrm{OCH}_{3}$

5: $\mathrm{R}=\mathrm{Glc}, \mathrm{R}^{1}=\mathrm{OH}$

6: $\mathrm{R}=$ Glc-rha, $\mathrm{R}^{1}=\mathrm{OH}$

Figure 2: Chemical structures of the isolated compounds from S. secundiflora (Ortega) Lag. ex DC leaves. 
the terminal $\alpha$-rhamnosyl moiety with a characteristic doublet signal of $\mathrm{CH}_{3}-6$ "'at 0.99 (d, $J=6 \mathrm{~Hz}$ ). The downfield location $\mathrm{H}-6$ " at $\delta 3.72$ was confirmative evidence for $\left(1^{\prime \prime \prime} \rightarrow 6 "\right)$ rhamno-glucoside linkage. Like previous quercetin compound the $\mathrm{ABX}\left(\mathrm{H} 2^{\prime} / 6^{\prime}, 5^{\prime} \mathrm{B}\right.$-ring) and $\mathrm{AM}(\mathrm{H}-$ 8, H-6, A-ring) spin coupling systems were confirmative documents in their $\delta$ and $J$-values of quercetin aglycones..$^{26,27}{ }^{13} \mathrm{C}$ NMR spectrum of compound 4 was directly proved the methoxylation on C-3' due to the appearance of the methoxy resonance at $\delta 56.8$ and the second one was the $\alpha$-downfield shift of C-3' to $147.4(\Delta \sim+3 \mathrm{ppm})$ and $\beta$-upfield of C-2' at $115.7(\Delta \sim-3 \mathrm{ppm})$ relative to these of quercetin. ${ }^{26}$ Also, fifteen typical carbon resonances for a quercetin moiety were assigned in the aromatic region of the spectrum of compound $\mathbf{5}$, among which the characteristic position of C-3 (133.7 ppm) to confirm the $O$-glucosidation at C-3. In addition, the two key signals of quercetin aglycone were assigned at $\delta$ $148.5\left(\mathrm{C}-4^{\prime}\right)$ and $145.3\left(\mathrm{C}-3^{\prime}\right) \mathrm{ppm}$. Compound 5 showed characteristic six carbon resonances in the aliphatic region of ${ }^{13} \mathrm{C}$ NMR spectrum. While twelve carbon resonances of glucose and rhamnose moieties were observed in ${ }^{13} \mathrm{C}$ NMR spectrum of compound $\mathbf{6}$. The terminal attachment of the rhamnosyl moiety to C-6" of glucoside, was confirmed from the characteristics downfield location of C- 6 " to 67.7 $(\sim \Delta+7, \alpha$ effect) and up-field location of C-5" to $76.6,(\sim \Delta-1-1.5 \mathrm{ppm})$ due to $(1 " ' \rightarrow 6 ")-O$-glycoside. They were identified as isorhamnetin (4) and two quercetin derivatives quercetin 3-glucoside (5) and quercetin 3-rutinoside (6).

\section{Quantitative determination of total phenolics, flavonoids and tannins content}

Phytochemical investigation of EaE of S. secundiflora leaves has revealed the total polyphenols content expressed as gallic acid equivalent (GAE) was $12.36 \pm 0.30 \mathrm{mg}$ GAE/g dry weight (D.W.) extract. The content of flavonoids was $5.80 \pm 0.15 \mathrm{mg}$ expressed as quercetin equivalent $(\mathrm{QE})$, while it exhibited $1.05 \pm 0.08 \mathrm{mg} / \mathrm{g}$ D.W. of tannins content. Each value represents the mean of 3 replicates (mean $\pm S D$ ).

\section{Immunomodulatory activity}

The biological study was planned to assess the immunomodulatory role of a hydroalcoholic extract and its organic fractions of S. secundiflora leaves and the major isoflavones $\mathbf{1}$ and $\mathbf{2}$ on both cell- and antibodymediated immune responses in APMV-vaccinated group treated with the investigated samples. Increases of the hemagglutinating antibodies in all the investigated samples were recorded. The treated groups with the $\mathrm{Ea} \mathrm{E}, \mathrm{Te} \mathrm{E}$ and $\mathrm{He} \mathrm{E}$ showed higher remarkable increase of the hemagglutinating antibodies titer. At the $7^{\text {th }}$ day, each group was separately vaccinated with live attenuated virus. These groups recorded high antibody titers of $2^{11.0}, 2^{10.8}$, and $2^{10.0}$, respectively at 28 days-post vaccination peak titer (Table 1 ). The vaccinated control group was that vaccinated only (at the $7^{\text {th }}$ day) with live attenuated APMV-1 vaccine (Table 1). The treated groups with $\mathrm{BuE}$ and isoflavones $\mathbf{1}$ and 2 gave a slight increase in the antibodies titer $\left(2^{8.0}, 2^{8.9}\right.$, and $2^{8.8}$, respectively) in comparison with control which recorded $2^{8.1}$ at the $28 \mathrm{DPV}$.

There was remarkable and progressive increase in the macrophage activity with the ethyl acetate EaE, crude total ethanol TeE and $n$-hexane $\mathrm{HeE}$ treated groups .All the groups showed maximum values of lymphocyte transformation at the $14^{\text {th }} \mathrm{DPV}$ which were expressed as delta optical density (Table 2). These maximum values reached 0.179 , 0.176 and 0.174 with $\mathrm{EaE}, \mathrm{TeE}$ and $\mathrm{HeE}$, respectively. The avian virus was considered as the antigen and the use of phyto hemagglutinating (PHA) as a mitogen in comparison. At the $14^{\text {th }} \mathrm{DPV}$, the vaccinated non-treated group showed a PHA value of 0.134 . While the vaccinated and treated groups recorded increase in values of PHA compared with the vaccinated non-treated control groups. The highest values were

\section{Table 1: The average log2 of heamagglutination inhibition (HI) titer to avian paramyxovirus serotype-1 (APMV-1) in pigeons.}

\begin{tabular}{|c|c|c|c|c|c|}
\hline \multicolumn{6}{|c|}{ HI } \\
\hline Group & 7 & 14 & 21 & 28 & 35 \\
\hline Control & 0.0 & 0.0 & 0.0 & 0.0 & 0.0 \\
\hline Vaccinated control & $2^{3.4}$ & $2^{6.6}$ & $2^{7.6}$ & $2^{8.1}$ & $2^{7.5}$ \\
\hline $\mathrm{TeE}$ & $2^{3.9}$ & $2^{6.4}$ & $2^{9.8}$ & $2^{10.8}$ & $2^{8.5}$ \\
\hline $\mathrm{HeE}$ & $2^{3.1}$ & $2^{5.9}$ & $2^{9.3}$ & $2^{10.0}$ & $2^{8.0}$ \\
\hline $\mathrm{EaE}$ & $2^{4.2}$ & $2^{6.9}$ & $2^{10.2}$ & $2^{11.0}$ & $2^{9.0}$ \\
\hline $\mathrm{BuE}$ & $2^{2.4}$ & $2^{3.9}$ & $2^{7.1}$ & $2^{8.0}$ & $2^{6.9}$ \\
\hline Compound 1 & $2^{2.8}$ & $2^{4.9}$ & $2^{8.0}$ & $2^{8.9}$ & $2^{7.2}$ \\
\hline Compound2 & $2^{2.6}$ & $2^{4.7}$ & $2^{7.9}$ & $2^{8.8}$ & $2^{7.0}$ \\
\hline
\end{tabular}

TeE; Hydroalcoholic (70\% Aqueous ethanol) extract, HeE; Hexane extract, EaE; Ethyl acetate extract; BuE, $n$-Butanol extract, Compound 1: Genistein 4'-Methyl ether (Biochanin A), Compound 2; 4'-Methoxydaidzein (Biochanin B).

Table 2: Cell-mediated immune response following a vaccination of pigeons with APMV and treatment with the investigated samples.

\begin{tabular}{|c|c|c|c|c|c|c|c|c|}
\hline \multirow[t]{2}{*}{ Group } & \multicolumn{2}{|c|}{7} & \multicolumn{2}{|l|}{14} & \multicolumn{2}{|l|}{21} & \multicolumn{2}{|l|}{35} \\
\hline & $\mathrm{PHA}^{\mathrm{a}}$ & APMV-1 ${ }^{\mathrm{b}}$ & PHA & APMV-1 & PHA & APMV-1 & PHA & APMV-1 \\
\hline Control & 0.010 & 0.011 & 0.007 & 0.012 & 0.011 & 0.013 & 0.008 & 0.007 \\
\hline Vaccinated & 0.101 & 0.121 & 0.134 & 0.168 & 0.112 & 0.159 & 0.079 & 0.081 \\
\hline TeE-treated & 0.108 & 0.130 & 0.140 & 0.176 & 0.115 & 0.164 & 0.084 & 0.093 \\
\hline HeE-treated & 0.104 & 0.128 & 0.136 & 0.174 & 0.112 & 0.162 & 0.079 & 0.089 \\
\hline EaE-treated & 0.110 & 0.134 & 0.142 & 0.179 & 0.118 & 0.166 & 0.086 & 0.096 \\
\hline Compound 1-treated & 0.102 & 0.122 & 0.131 & 0.164 & 0.110 & 0.138 & 0.076 & 0.082 \\
\hline Compound 2-treated & 0.103 & 0.124 & 0.129 & 0.166 & 0.111 & 0.159 & 0.077 & 0.085 \\
\hline
\end{tabular}

TeE-treated; The group treated with hydroalcoholic (70\% aqueous ethanol) extract, HeE-treated; The group treated with hexane extract, EaE-treated; The group treated with ethyl acetate extract; BuE-treated; The group treated with $n$-Butanol extract, Compound 1-treated; The group treated with genistein 4 '-methyl

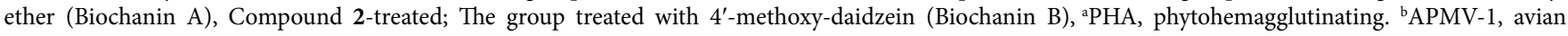
paramyxovirus serotype-1. 
recorded for the group treated with ethyl acetate $\mathrm{EaE}$ (0.142) and hydroalcoholic extract TeE (0.140) (Table 2).

On the other hand, more assertion for the former results was obtained after evaluation of the macrophage activity (Table 3). A maximum phagocytic activity was 69.60 in the 14 DPV vaccinated group, while remarkable increase in vaccinated and treated groups with $\mathrm{EaE}$ (74.05), $\mathrm{HeE}$ (73.45) and TeE (73.20). While the vaccinated and treated groups with compounds $\mathbf{1}$ and $\mathbf{2}$ showed nearly the same phagocytic activity (72.23 and 72.18, respectively). The immune status of the birds was reflected by recording the number of pigeons has symptoms of disease and the number of the protected birds (Table 4). The vaccinated groups showed a maximum protection of $66.6 \%$ at the $14 \mathrm{DPV}$. The protection percentage of the vaccinated EaE-treated groups of birds at the DPV of $3,14,21$ and 35 were $53,87,100$, and $80 \%$, respectively.

\section{Investigation of in vitro antioxidants activities}

The crude TeE, BuE, HeE, EaE extracts and major isoflavones (compounds 1 and 2) of $S$. secundiflora were investigated for their antioxidant capacities (Figures $3 \mathrm{a}-\mathrm{c}$ ). EaE extract recorded the highest radical scavenging activity using DPPH assay it found to be $85.07 \pm$ $0.65 \%$ at the concentration of $0.5 \mathrm{mg}$ followed by TeE $(60.43 \pm 0.97 \%)$. The lowest DPPH radical scavenging activity between examined extracts was $20.07 \pm 0.28 \%$ for compound 2 (Figure $3 a$ ).

Figure $3 \mathrm{~b}$ described the reducing power of the six investigated samples. As can be seen, EaE extract showed the highest antioxidant property $(1.61 \pm 0.02)$ at the concentration of $0.5 \mathrm{mg} / \mathrm{mL}$, indicating that it was effective as an antioxidant. Both $\mathrm{TeE}$ and $\mathrm{BuE}$ exhibited moderate reducing power ability. They recorded $0.90 \pm 0.03$ and $0.83 \pm 0.04$, respectively.

The radical-scavenging activity of plant samples and major isoflavones (compounds 1 and 2) which was determined by ABTS radical cation decolorization assay was shown in Figure $3 \mathrm{c}$. TeE, BuE, $\mathrm{HeE}, \mathrm{EaE}$ fractions, were $65.53 \pm 0.41,62.79 \pm 0.38,27.82 \pm 26$ and $75.77 \pm$ $0.33 \%$ respectively $(0.5 \mathrm{mg} / \mathrm{mL})$, while compounds 1 and 2 were 29.38 \pm 0.46 and $26.16 \pm 0.19 \%$ ABTS radical scavenging activity at the same concentration. These results were as near as to those of DPPH and reducing power assays.Findings from this study indicated that all the investigated samples showed radical scavenging effect in the order of $\mathrm{EaE}>\mathrm{TeE}>\mathrm{BuE}>$ Compound $\mathbf{1}>$ Compound $\mathbf{2}>\mathrm{HeE}$.

\section{DISCUSSION}

Recently there has been an upsurge of interest in the multipronged therapeutic potential of medicinal plants containing isoflavones. ${ }^{2,5}$ Oral administration of some medicinal herbs to improve immunization has been reported previously. ${ }^{2,28}$ The crude extracts, herbal formulations or isolated compounds from many medicinal plants could be used as adjuvant and exhibit strong immunomodulatory function. ${ }^{5,29}$ Adjuvants play an important role in the development of vaccines. Many plants based vaccine adjuvant were reported for their immunostimulatory activity and their potential role as an alternative adjuvant for improving and maintaining the improved immune status. ${ }^{30,31}$ The present study was designed to investigate the effect of oral administration of different

Table 3: The activities of the investigated samples on the macrophages phagocytosis of Candida albicans.

\begin{tabular}{|c|c|c|c|c|c|c|c|c|c|c|c|c|c|c|}
\hline \multirow[t]{2}{*}{ Days Group } & \multicolumn{2}{|c|}{3} & \multicolumn{2}{|c|}{7} & \multicolumn{2}{|c|}{10} & \multicolumn{2}{|c|}{14} & \multicolumn{2}{|c|}{21} & \multicolumn{2}{|c|}{28} & \multicolumn{2}{|c|}{35} \\
\hline & $\mathrm{PH}-\%{ }^{\mathrm{a}}$ & $\mathrm{PH}-\mathrm{I}^{\mathrm{b}}$ & PH-\% & $\mathrm{PH}-\mathrm{I}$ & PH-\% & PH-I & PH-\% & PH-I & PH-\% & PH-I & PH-\% & $\mathrm{PH}-\mathrm{I}$ & PH-\% & PH-I \\
\hline Control & 16.09 & 0.05 & 11.05 & 0.05 & 11.90 & 0.07 & 14.00 & 0.13 & 13.00 & 0.06 & 10.90 & 0.06 & 16.10 & 0.07 \\
\hline Vaccinated & 44.60 & 0.42 & 56.30 & 0.41 & 75.90 & 0.58 & 69.60 & 0.49 & 69.80 & 0.57 & 53.20 & 0.39 & 41.09 & 0.29 \\
\hline TeE-treated & 48.90 & 0.44 & 57.90 & 0.43 & 76.10 & 0.63 & 73.20 & 0.58 & 73.70 & 0.61 & 55.80 & 0.44 & 46.80 & 0.33 \\
\hline HeE-treated & 48.60 & 0.41 & 57.60 & 0.41 & 69.90 & 0.60 & 73.45 & 0.54 & 73.10 & 0.59 & 55.70 & 0.41 & 46.10 & 0.31 \\
\hline EaE-treated & 49.60 & 0.46 & 58.40 & 0.45 & 78.60 & 0.66 & 74.05 & 0.60 & 74.00 & 0.63 & 56.00 & 0.45 & 47.20 & 0.36 \\
\hline BuE-treated & 44.90 & 0.31 & 54.80 & 0.34 & 65.90 & 0.49 & 69.76 & 0.46 & 69.80 & 0.51 & 54.30 & 0.39 & 42.10 & 0.22 \\
\hline $\begin{array}{c}\text { Compound } \\
\text { 1-treated }\end{array}$ & 47.90 & 0.39 & 56.90 & 0.38 & 69.10 & 0.59 & 72.23 & 0.51 & 72.10 & 0.57 & 54.90 & 0.38 & 44.70 & 0.29 \\
\hline $\begin{array}{c}\text { Compound } \\
\text { 2-treated }\end{array}$ & 48.10 & 0.40 & 57.10 & 0.39 & 69.40 & 0.56 & 72.18 & 0.52 & 72.20 & 0.58 & 55.10 & 0.39 & 44.80 & 0.28 \\
\hline
\end{tabular}

TeE-treated; The group treated with hydroalcoholic (70\% aqueous ethanol) extract, HeE-treated; The group treated with hexane extract, EaE-treated; The group treated with ethyl acetate extract; BuE-treated; The group treated with $n$-Butanol extract, Compound 1-treated; The group treated with genistein 4 '-methyl ether (Biochanin A), Compound 2-treated; The group treated with 4'-methoxy-daidzein (Biochanin B), ${ }^{\text {a }} \mathrm{PH}-\%$; phagocytic percentage, ${ }^{\mathrm{b}} \mathrm{PH}-\mathrm{I}$; phagocytic index.

Table 4: The percentage of protection following the vaccination of pigeons with APMV at various intervals between challenges.

\begin{tabular}{|c|c|c|c|c|c|c|c|c|c|}
\hline \multirow{2}{*}{ Groups } & \multicolumn{5}{|c|}{ Number of pigeons have symptoms of disease } & \multicolumn{4}{|c|}{ Numbers of protected (The protection percentage) } \\
\hline & days & 3 & 14 & 21 & 35 & 3 & 14 & 21 & 35 \\
\hline Control & & 15 & 15 & 15 & 15 & $0(0)$ & $0(0)$ & $0(0)$ & $0(0)$ \\
\hline Vaccinated & & 9 & 5 & 2 & 6 & $6(40.0)$ & $10(66.6)$ & $13(86.6)$ & $9(60.0)$ \\
\hline TeE-treated & & 9 & 2 & 1 & 3 & $6(40.0)$ & $13(90.0)$ & $14(93.3)$ & $12(80.0)$ \\
\hline HeE-treated & & 10 & 5 & 2 & 4 & $5(33.3)$ & $10(66.6)$ & $13(86.6)$ & $11(73.3)$ \\
\hline EaE-treated & & 7 & 2 & 0 & 3 & $8(53.3)$ & $13(86.6)$ & $15(100.0)$ & $12(80.0)$ \\
\hline BuE-treated & & 14 & 8 & 5 & 7 & $1(6.6)$ & $7(46.6)$ & $10(66.6)$ & $8(53.3)$ \\
\hline $\begin{array}{l}\text { Compound } \\
\text { 1-treated }\end{array}$ & & 13 & 7 & 3 & 5 & $5(33.3)$ & $8(53.3)$ & $12(80.0)$ & $10(66.6)$ \\
\hline $\begin{array}{l}\text { Compound } \\
\text { 2-treated }\end{array}$ & & 6 & 6 & 3 & 6 & $2(13.3)$ & $9(60.0)$ & $12(80.0)$ & $9(60.0)$ \\
\hline
\end{tabular}

TeE-treated; The group treated with hydroalcoholic (70\% aqueous ethanol) extract, HeE-treated; The group treated with hexane extract, EaE-treated; The group treated with ethyl acetate extract; BuE-treated; The group treated with $n$-Butanol extract, Compound 1-treated; The group treated with genistein 4'-methyl ether (Biochanin A), Compound 2-treated; The group treated with 4'-methoxy-daidzein (Biochanin B). Values in parentheses represent the protection percentage. 

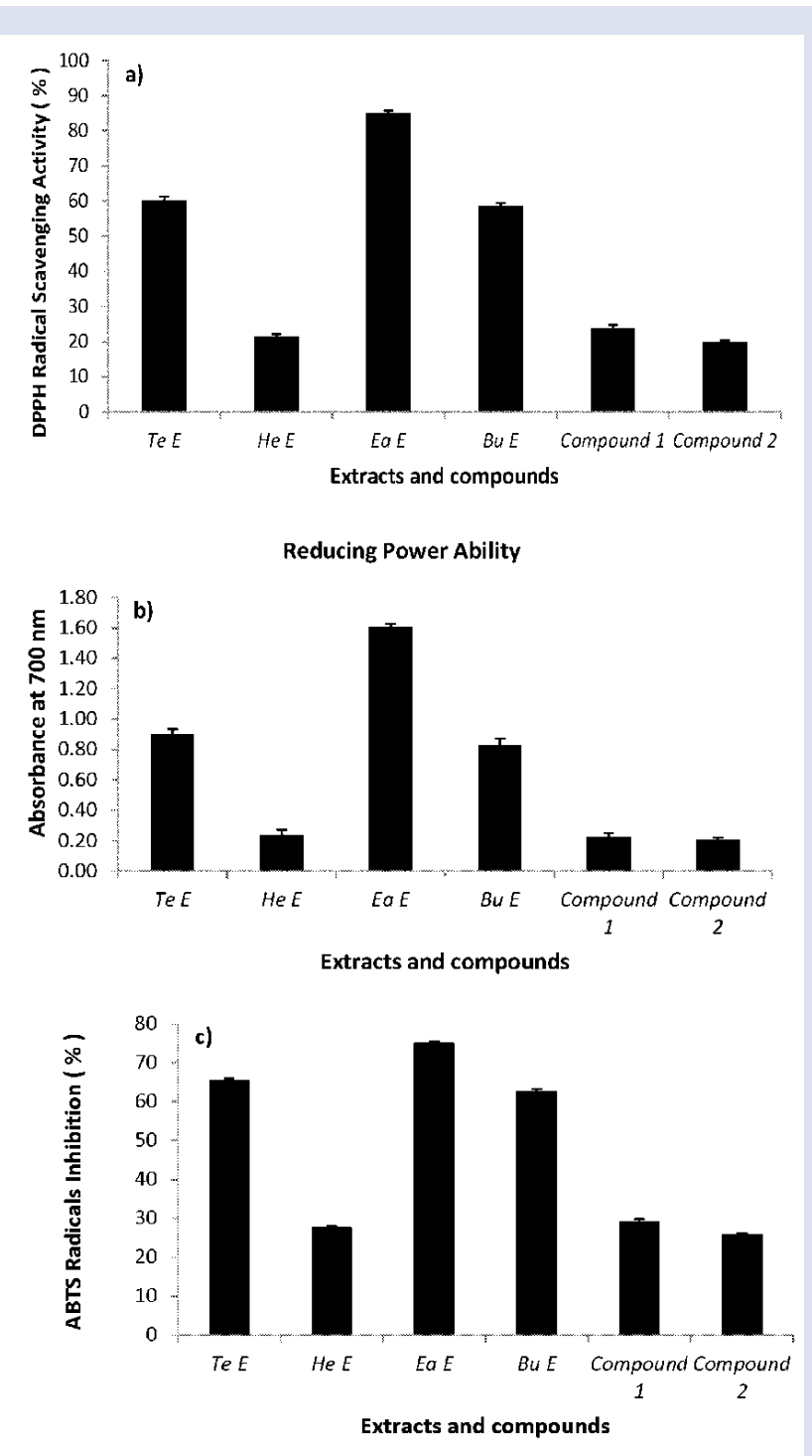

Figure 3: Antioxidant activity of the extracts and isolated compound of S. secundiflora $(0.5 \mathrm{mg}$ dried sample $/ \mathrm{mL})$. a) DPPH Free radical scavenging activity; b) Reducing power activity; c) Radical cation ABTS scavenging activity.

samples on the cellular and humoral immune responses to live attenuated APMV vaccines in pigeons.

Various studies suggest that phenolic compounds, specifically the flavonoids promoted the secondary immune response and modulate host resistance. ${ }^{29,32-34}$ Our current study showed the isolated and identified of three flavonoids 4 - $\mathbf{6}$ for the first time from S. secundiflora. Also, 5-7-dihydroxy-4'-methoxyisoflavone (biochanin A) 1 and 7-hydroxy-4'methoxyisoflavone (formononetin) 2 were isolated and identified. Mansoori et al. ${ }^{35}$ reported the immunomodulatory activity of the methoxy isoflavones formononetin and isoformononetin which were suggested to translate into improved skeletal parameters, thereby preventing ovariectomized -induced bone loss. The activity of the TeE of the plant under investigation may be due to polyphenols component as tannins and isoflavones. Our previous studies have shown that another isoflavone (genistein-8-C-glucoside), isolated from Retama raetam seeds, had an inhibitory activity against reactive nitrogen species derived from nitric oxide. ${ }^{3}$ These components may reduce lipid peroxidation products and enhancing contents of antioxidants and activities of relevant antioxidase enzymes and increased contents of cytokine. $^{5}$

As a result of the present study the stimulation of both seroresponses in the vaccinated group treated with the investigated sample, especially this of EaE has been confirmed. The antibody titers showed a remarkable increase as well as the lymphocyte and macrophage cells in blood. Our results showed the identification of 4'-methoxy-daidzein 2. One of the common metabolites of daidzein and formononetol is equol. It is a nonsteroidal estrogen of the isoflavone class. ${ }^{36}$ This metabolite was reported to inhibit lipopolysaccharide induced-oxidative stress and reduces lipid peroxidation products. Equol is shown to protect intestinal epithelial cells from oxidative damage and enhances the immune response in HD11 macrophages of chicken. ${ }^{36}$

EaE of S. secundiflora leaves has revealed the highest total polyphenols, flavonoids and tannins content. Antioxidant-rich plants exhibited the prevention of oxidative-stress-related diseases. The present results demonstrated a linear relationship of antioxidant activities of the investigated samples (such as total crude extract and its organic fractions) with their phenolics, flavonoids and tannins content. The TeE extract and its organic fractions of S. secundiflora and two methoxyisoflavones showed antioxidant capacity (Figure 3 ). The pronounced radical scavenging activities of TeE and EaE extracts compared to other samples may have attributed to their higher lipid peroxidation reducing capabilities by acting as antioxidants. This effect may be aid the endogenous antioxidant enzymes involved in the inactivation of ROS before lipid peroxidation takes place. ${ }^{5}$

Genus of Sophora is endowed with antiradical molecules., ${ }^{3,5}$ The high reducing power of the TeE and EaE extracts of S. secundiflora leaves (Figure 3 ) is probably because of their hydrogen donating ability. ${ }^{37}$ They act as electron donors and could alleviate the number of oxidative stress. The donor reacts with free radicals to convert them into more stable products and then terminate the free radical chain reaction. Both extracts demonstrated antioxidant capacity and immune modulating activity at the present study. Other bioactive metabolites as resveratrol oligomers have been isolated from the genus Sophora. ${ }^{38}$ Stilbenoids including resveratrol promoted rapid and transient release of free radicals/ reactive oxygen species (ROS). ${ }^{39}$ The anti-herpetic activity of oligomeric stilbenoids to innate immunity was reported. ${ }^{40}$ They inhibit herpes simplex virus infection through free radicals/ROS generation. Effect of diethylstilboestrol (DES) compounds on the phagocytic activity of the reticulo-endothelial system was reported. ${ }^{39}$ DES neonatal treatment in male and female mice affected the immune cell percentage. Pterocarpan glycosides isolated from S. tonkinensis were reported to inhibit the production of nitric oxide induced by lipopolysaccharide in RAW 264.7 macrophages. ${ }^{41}$ Apterocarpan and indigocarpan from Indigofera aspalathoides have exhibited a strong antioxidative effect in human colorectal adenocarcinoma LS174T cells. ${ }^{42}$

In our work the vaccinated and treated groups with ethyl acetate EaE recorded the highest values of PHA compared with the vaccinated non-treated control groups. Currently, studies have found that the EaE fraction of Sophora contain other bioactive constituents such as alkaloids, saponins and polysaccharides. ${ }^{5}$ Quinolizidine alkaloids of matrine-type were isolated from the roots and rhizomes of $S$. tonkinensis and have showed potent anti-hepatitis B virus (HBV) activity with an inhibitory potency against hepatitis B surface antigen HBsAg. ${ }^{31}$ Wang and his co-authors ${ }^{43}$ have suggested that the alkaloids belongs to this class when combined with thymopolypeptides, they could inhibit HBV DNA replication, and further promote the antiviral effect by promoting the expression of IFN- $\alpha^{43}$ Therefore, in our present study, the high activity of EaE fraction may be attributed to the synergistic in its biological activity, including in vitro antiviral and immunomodulatory activities. $^{43}$ 
Many studies have reported that flavonoids isolated from Sophora root act as antibacterial, anti-inflammatory and immunoregulatory. In our present work, two $O$-methylated isoflavones; 4'-methyl ethers of genistein (1) and daidzein (2) were identified in the plant leaves. These compounds may exhibit stimulating properties on natural killer cell activity. ${ }^{32}$ The importance of cell-mediated immune response during disease infections and its implications for the development of effective vaccines was reported. ${ }^{44}$ The activity of APMV vaccinated groups, as a result of the treatment with successive plant extracts (TeE, $\mathrm{EaE}$, and $\mathrm{BuE}$ ), might be ascribed to the ability of polyphenolics to reduce oxidative stress, improving the membrane integrity of the cells and enhance the innate immune function. ${ }^{33}$ Treatment of vaccinated group with EaE extract, containing the 4'-methoxyisoflavones $\mathbf{1}$ and $\mathbf{2}$, may prevent oxidative damage by detoxifying ROS/ free radicals. An effective immune response for preventing of many diseases is related with the activities of antibody via the complement activation and antibody-dependent cell-mediated cytotoxicity pathway, macrophage and T-cell. ${ }^{45}$ Table 3 showed a maximum phagocytic activity in vaccinated control group the $14 \mathrm{DPV}$. Production of oxygen radicals and nitric oxide by activated macrophages is important for their cytopathic effects. In the vaccinated and treated groups with $\mathrm{EaE}, \mathrm{HeE}$ and $\mathrm{TeE}$, there were remarkable macrophage activations as they recorded 74.05 , 73.45 , and 73.20, respectively. While vaccinated isoflavones compounds (1 and 2) treated groups have showed nearly the same phagocytic activity. Isoflavone daidzein can up-regulate interleukin-4 production in activated $\mathrm{T}$ cells and increase phagocytic response of peritoneal macrophages. ${ }^{8}$

The enhanced immune responses may be related to immunocompetent cells activated by treatment with the natural products before vaccination, as reported. ${ }^{8}$ Many studies justified that the diverse bioactivities of Sophora species might due to the presence of high-added-value polyphenolic components, including isoprenylated flavonoids and stilbenes in Sophora species. ${ }^{2,5}$ Isoprenylated flavonoids are a class of flavonoids with diverse structures and some of those showed antiviral and antioxidant bioactivities. ${ }^{46}$ These compounds may inhibit the expression of pro-inflammatory mediators and cytokines, including NO in immune cells. These compounds possess strong antioxidant properties that enable them to scavenge free radicals, donate hydrogen, chelate metals, break radical chain reactions, and quenchsinglet oxygen in vitro and in vivo. ${ }^{5,21}$ The six samples were evaluated as antioxidant agents using the three antioxidant bioassay tests. In the present study, The TeE and EaE extracts showed remarkable results, followed by the isoflavone 1 . There were positive relationship between the radical scavenging activity of TeE, BuE and EaE and their total phenolic, tannins and flavonoids content. Similar relationships have been widely reported in many plants. ${ }^{3,33}$ The difference in antioxidant potential of the extracts may be related to variation in the percentage of phytoconstituents extracted in various solvents. HeE sample has exhibited good antioxidant activity, although it contains less polyphenolic content than other samples. The difference in the type of polyphenolic content may be attributed to this recorded activity or the presence of antioxidantactive nonphenolic compounds. ${ }^{47}$

DPPH assay constitutes a quick, simple and low cost method, which has been widely used to determine the ability of a substance to act as a radical scavenger or hydrogen donor. Our preliminary phytochemical screening of the of S. secundiflora (Ortega) Lag. ex DC leaves showed the presence of various polyphenols such as coumarins, flavonoids, sterols and/or triterpenes, tannins as well as alkaloids in the crude extract $(\mathrm{TeE})$. These phytoconstituents might have a role to stabilize free radicals, chelating transition metals, inhibition of peroxidation or scavenging ROS and these may reflect the integrated antioxidant status. $^{3}$ The reductive capability of substances using potassium ferricyanide reduction assay is correlated with their content of electron donors such as polyphenols as isoflavones. ${ }^{48}$ This result is in agreement with the previously reported about $S$. japonica that have high content of polyphenolic constituents including: tamarixetin, sissotrin, gallic acid, and ellagic acid 4-O- $a$-L-arabinofuranoside, and showed good antioxidant capacity. ${ }^{2}$

The influence of many plant-derived secondary metabolites like flavonoids on immune function has been examined extensively. ${ }^{32}$ Quercetin glycosides have many hydroxyl groups and have been possessed strong scavenging ability for free radicals. ${ }^{49}$ In our present work, two quercetin glycosides quercetin 3-glucoside and quercetin 3-rutinoside were isolated through bioassay-guided fractionation of the EaE fraction of $S$. secundiflora leaves. Quercetin glycosides were reported as equally effective in suppressing lipid peroxidation in 6-hydroxydopamine-induced pheochromocytoma PC-12 cells as they suppressed the malondialdehyde generation and prevented cell damage. Also, Valentová et al. ${ }^{50}$ recorded that many quercetin derivatives showed significant antimutagenic activity and DNA-protective effects against oxidative damage. Isoflavones have chemical structures similar to estrogen and so they are sometimes referred to as phytoestrogens. ${ }^{10}$ The B-ring of flavonoid is linked to the $\mathrm{C}_{3}$ position of the $\mathrm{C}$-ring instead of the $\mathrm{C}_{2}$ position in the isoflavone molecule. Our results in the present study show compound $\mathbf{1}$ to be more biologically active as compared to compound 2 . The proposed mechanism for immuno-regulation by these isoflavones may be related to their estrogenic actions. ${ }^{10}$ Also; the presence of 5-hydroxyl group at A-ring might be of certain importance to the immuno-regulation and antioxidant activity of compounds $1 \mathrm{vs}$ 2. ${ }^{51}$

Medicinal plants with antioxidant activity could also have immunomodulatory ability. ${ }^{50}$ Our previous research found that a supplement of the extract made from Jatropha curcus leaves in commercially inactivated Newcastle disease vaccines could significantly enhance the immune responses in chickens..$^{28}$ One of the herbal plants acts as immunomodulator is $S$. subprosrate. The polysaccharides extracted from the plant stimulated proliferation of murine splenic lymphocytes in immunosuppressed mice.,52 The extract TeE and its fractions were administered orally to the experimental groups of pigeons. This may be related to the mucosal immunity of birds. Wang et al. ${ }^{43}$ reported the potentiating intestinal mucosal immunity of miceafter oral administration of a polyphenol-enriched extract of a Chinese herbal formula. Isoflavonoids isolated from some medicinal plants have been proven to possess immunomodulatory effect. ${ }^{1,3,52}$ It is therefore possible that the effect observed within the extract of EaE and BuE may be attributable to their isoflavonoids component that regarded as protective antioxidants based on their ability to donate hydrogen atom to free radicals. Findings from this study indicate the presence of promisingly potent phytoconstituents in EaE and these may be attributed to its capability to act as antioxidants and free radical scavengers. The aqueous extract of $S$. tonkinensis could induce the apoptosis of mouse lymphoma, and contained immune modulators for promoting the anti-lymphoma properties in vivo. ${ }^{53}$ Compound 1 (5,7-dihydroxy-4'-methoxyisoflavone) contain $\mathrm{OH}$ group, suggesting that the hydroxyl moiety is a critical structure that increases the antioxidant and immunomodulatory activity. ${ }^{3,28,30}$ The results reveal that, the presence of $-\mathrm{OH}$, in the isoflavonoid skeleton, enhanced the immunomodulatory activity.

The presence of a variety of classes of flavonoids in the investigated samples such as flavones (apigenin derivatives), flavonols (quercetin derivatives) and isoflavones (5,7-dihydroxy- and 7-hydroxy4'-methoxyisoflavone) may be show a synergistic effect against paramyxovirus disease and also the potent antimutagenic activity. ${ }^{5,54}$ Flavonol quercetin was also reported to enhance natural killer cell killing activity towards mouse Cr-labelled lymphoma YAC-1 target cells. ${ }^{32,51}$ 
In our study, the isolation of quercetin derivatives as quercetin 3-glucoside (5) and quercetin-3-rutinoside (6), were reported as effective and other flavonols against viruses ${ }^{34}$ was carried out. The most common isoflavones genistein and daidzein are also found as the 4'-methyl ethers compound $\mathbf{1}$ and formononetol, respectively in the extract of EaE. ${ }^{9}$ Most in vivo studies discussed the effect of isoflavones on immune functions are those for genistein. ${ }^{8}$ This compound affects antibody- and cell-mediated immune responses and is known to control general immune function. ${ }^{8}$ It inhibits lymphocyte proliferation and thymocyte differentiation. The suppressive activity of isoflavonoids against lymphocyte proliferation was reported. ${ }^{51}$

Based on these findings, we postulate that $\mathrm{EaE}$ and BuE have immunomodulatory potential for the development of an effective strategy against paramyxovirus. The strategy would likely have no toxic side-effects. Therefore, these extracts may be considered as immunestimulatory potentiators. The respective 4'-methoxy derivative of genistein biochanin A has showed remarkable activity.

Several researches suggest that the global combination of secondary metabolites produces synergistic pharmacological activity..$^{30,54-56}$ Phytochemical investigation of the EaE extract showed the presence of considerable amount of flavonoids and polyphenols like phenolic compounds and tannins. Therefore, it is possible to assert that the activities of the EaE are in suitable correlation with these chemical contents, once these classes of compounds are known as potent molecules with immune modulating and radical scavenging activity. ${ }^{3,33,49}$ The vaccinated groups showed a maximum protection of $66.6 \%$ at the 14 DPV. The protection percentage of the vaccinated and EaE-treated groups of birds at the DPV of 3,14, 21 and 35 were 53,87, 100, and $80 \%$, respectively (Table 4 ). Collectively, our findings indicate that oral administration of $S$. secundiflora especially the EaE fraction and the major isolated methoxyisoflavones $\mathbf{1}$ and $\mathbf{2}$ may have potential role in antibody-mediated immune response against paramyxovirus disease which is severely endangering out the poultry industry by causing economic losses. ${ }^{41}$

\section{CONCLUSION}

In this work, the extracts of $\mathrm{EaE}$ and $\mathrm{BuE}$ exert marked activity as immunomodulator that may be attributed to the presence of isoflavonoids in these extracts, what may provide a novel approach to the development of plant-based vaccine adjuvant. Our study should provide new insights for further pertinent investigations to establish the action mechanisms of the isolated compounds.

This can be deduced that the tested fractions from ethanolic extract of S. secundiflora and isoflavones have remarkable antioxidant(s), along with immunoregular activities. Our findings have suggested that they could impart health benefits in the vaccinated pigeons against APMV1 .

\section{ACKNOWLEDGMENT}

The authors are grateful to Prof. Dr. Mounir M. El-Safty, CLEVB, Cairo, Egypt for providing facilities to carry out the immunomodulatory activity.

\section{REFERENCES}

1. Abd-Alla HI, Heba-tollah MS, El-Kashak WA, El-Safty MM Evaluation of immune boosting properties and combating of multiple respiratory viral infections by fifteen Euphorbiaceae plant extracts. Pharmacognosy Journal. 2019:11(6s):1490-503.

2. Krishna PM, KNV R, Banji D.A review on phytochemical, ethnomedical and pharmacological studies on genus Sophora, Fabaceae. Revista Brasileira de Farmacognosia. 2012;22(5):1145-54.

3. Awad HM, Abd-Alla HI, Mahmoud KH, El-Toumy SA. In vitro anti-nitrosative, antioxidant, and cytotoxicity activities of plant flavonoids: a comparative study. Medicinal Chemistry Research. 2014;23(7):3298-307.
4. Conti BJ, Santiago KB, Búfalo MC, Herrera YF, Alday E, Velazquez C, Hernandez $J$, Sforcin JM. Modulatory effects of propolis samples from Latin A merica (Brazil, Cuba and Mexico) on cytokine production by human monocytes. Journal of Pharmacy and Pharmacology. 2015;67(10):1431-8.

5. He X, BaiY, Zhao Z, Wang X, Fang J, Huang L, Zeng M, Zhang Q, Zhang Y, Zheng $X$. Local and traditional uses, phytochemistry, and pharmacology of Sophora japonica L.: A review. Journal of Ethnopharmacology. 2016;187:160-82.

6. Yao N, Wang X. In vitro immunomodulatory activity of oxymatrine on Toll-like receptor 9 signal pathway in chronic hepatitis B. The American Journal of Chinese Medicine. 2014;42(6):1399-410.

7. Shuai XH, Hu TJ, Liu HL, Su ZJ, Zeng Y, Li YH. Immunomodulatory effect of a Sophora subprosrate polysaccharide in mice. International Journal of Biological Macromolecules. 2010;46(1):79-84.

8. Gupta C, Prakash D. Phytonutrients as therapeutic agents. Journal of Complementary and Integrative Medicine. 2014;11(3):151-69.

9. Yellayi S, Zakroczymski MA, Selvaraj V, Valli VE, Ghanta V, Helferich WG, Cooke PS. The phytoestrogen genistein suppresses cell-mediated immunity in mice. Journal of Endocrinology. 2003;176(2):267-74.

10. Cooke PS, Selvaraj V, Yellayi S. Genistein, estrogen receptors, and the acquired immune response. The Journal of Nutrition. 2006;136(3):704-8.

11. Wu DQ, Zhong HM, Ding $\mathrm{OH}, \mathrm{Ba}$ L. Protective effects of biochanin A on articular cartilage: in vitro and in vivo studies. BMC Complementary and Alternative Medicine. 2014;14(1):444.

12. Hines NL, Miller CL. Avian paramyxovirus serotype-1: a review of disease distribution, clinical symptoms, and laboratory diagnostics. Veterinary Medicine International. 2012;2012.

13. Rohaim MA, El Naggar RF, Helal AM, Hussein HA, Le-Blanc N. Genetic characterization of pigeon paramyxovirus type 1 in Egypt. Brazelian Journal Virology. 2016;3(2):27-32

14. Office International Des Epizooties OIE. Manual of Standards for Diagnostic Tests and Vaccines. 4th ed. Paris, France, 2002.

15. Makkar HP, Becker K, Abel HJ, Pawelzik E. Nutrient contents, rumen protein degradability and antinutritional factors in some colour and white flowering cultivars of Vicia faba beans. Journal of the Science of Food and Agriculture. 1997;75(4):511-20

16. Ordonez AA, Gomez JD, Vattuone MA. Antioxidant activities of Sechium edule (Jacq.) Swartz extracts. Food Chemistry. 2006;97(3):452-8.

17. Charles $R$, Catpenter $A B$, Henry $R$, Bose JR. Suppression of the mitogenstimulated blastogenic response during reticuloendotheliosis virus induced tumorigenesis. Journal of Immunology. 1978;120(4):1313-20.

18. Mosmann T. Rapid colorimetric assay for cellular growth and survival: application to proliferation and cytotoxicity assays. Journal of Immunological Methods. 1983;65(1-2):55-63

19. Richardson MD, Smith H. Resistance of virulent and attenuated strains of Candida albicans to intracellular killing by human and mouse phagocytes. Journal of Infectious Diseases. 1981;144(6):557-64.

20. Brand-Williams W, Cuvelier ME, Berset CL. Use of a free radical method to evaluate antioxidant activity. LWT-Food Science and Technology. 1995;28(1):2530 .

21. Rice-Evans C, Re R, Pellegrini N, Proteggente A, Pannala A, Yang M. Antioxidant activity applying an improved ABTS radical cation decolorization assay. Free Radical Biology and Medicine. 1999;26:1231-7.

22. Oyaizu M, Jpn J. Studies on the product of browning reaction prepared from glucosamine. Nutrition. 1986;44: 307-315.

23. Tanaka $T$, Ohyama $M$, linuma $M$, Shirataki $Y$, Komatsu $M$. Isoflavonoids from Sophora secundiflora, S. arizonica and S. gypsophila. Phytochemistry. 1998;48(7):1187-93.

24. Mabry TJ, Markham KR, Thomaas MB. The systematic Identification of flavonoids, Springer-Verlag, Berlin, 1970

25. Markham ER, Geiger H. 1H NMR Spectroscopy of flavonoids and their glycosides in hexadeuterodimethylsulfoxide. Flavonoids, Harborne JB, Chapman and Hall, London, 1994.

26. Agrawal PK, Bansal MC. Flavonoid glycosides. In: Studies in Organic Chemistry 39, 13C-NMR of Flavonoids (Agrawal P. K., ed.). Elsevier Science, New York, USA, 1989;283.

27. Harborne JB, Mabry TJ. The flavonoids: advances in research. Chapman and Hall Ltd: New York, 1982

28. Abd-Alla HI, Moharram FA, Gaara AH, El-Safty MM. Phytoconstituents and immunomodulatory activity of Jatropha curcas L. leaves on humoral and cell-mediated immune response in chicks. Zeitschrift für Naturforschung C. 2009;64(7-8):495-501.

29. Abd-Alla HI, Heba-tollah MS, Mohamed TA, Gabr MM, El-Safty MM, Hegazy ME. Efficacy of extracts and iridoid glucosides from Pentas lanceolata on humoral and cell-mediated immune response of viral vaccine. Medicina Chemistry Research. 2017;26(9):2196-204. 
30. Bassani DC, Nunes DS, Granato D. Optimization of phenolics and flavonoids extraction conditions and antioxidant activity of roasted yerba-mate leaves (llex paraguariensis A. St.-Hil., Aquifoliaceae) using response surface methodology. Anais da Academia Brasileira de Ciências. 2014;86(2):923-34.

31. Ding $\mathrm{PL}$, Huang $\mathrm{H}$, Zhou $\mathrm{P}$, Chen DF. Quinolizidine alkaloids with anti-HBV activity from Sophora tonkinensis. Planta Medica. 2006;72(9):854-6.

32. Yu CS, Lai KC, Yang JS, Chiang JH, Lu CC, Wu CL, Lin JP, Liao CL, Tang NY, Wood WG, Chung JG. Quercetin inhibited murine leukemia WEHI-3 cells in vivo and promoted immune response. Phytotherapy Research. 2010;24(2):163-8.

33. Tietbohl LA, Oliveira AP, Esteves RS, Albuquerque RD, Folly D, Machado FP Correa AL, Santos MG, Ruiz AL, Rocha L. Antiproliferative activity in tumor cell lines, antioxidant capacity and total phenolic, flavonoid and tannin contents of Myrciaria floribunda. Anais da Academia Brasileira de Ciências. 2017; 89(2):1111 20.

34. Awad HM, Abd-Alla HI, Ibrahim MA, El-Sawy ER, Abdalla MM. Flavones from Heavenly Blue as modulators of Alzheimer's amyloid-beta peptide (A $\beta)$ production. Medicinal Chemistry Research. 2018;27(3):768-76.

35. Mansoori MN, Tyagi AM, Shukla P, Srivastava K, Dev K, Chillara R, Maurya $R$ Singh $D$. Methoxyisoflavones formononetin and isoformononetin inhibit the differentiation of Th17 cells and B-cell lymphopoesis to promote osteogenesis in estrogen-deficient bone loss conditions. Menopause. 2016;23(5):565-76.

36. Gou Z, Jiang S, Zheng C, Tian Z, Lin X. Equol inhibits LPS-induced oxidative stress and enhances the immune response in chicken HD11 macrophages. Cellular Physiology and Biochemistry. 2015;36(2):611-21

37. Zha $X Q$, Wang JH, Yang XF, Liang $H$, Zhao LL, Bao SH, Luo JP, Xu YY, Zhou $\mathrm{BB}$. Antioxidant properties of polysaccharide fractions with different molecular mass extracted with hot-water from rice bran. Carbohydrate Polymers. 2009;78(3):570-5.

38. Ohyama M, Tanaka T, linuma M. Five resveratrol oligomers from roots of Sophora leachiana. Phytochemistry. 1995;38(3):733-40.

39. Nava-Castro KE, Morales-Montor J, Ortega-Hernando A, Camacho-Arroyo I. Diethylstilbestrol exposure in neonatal mice induces changes in the adulthood in the immune response to Taenia crassiceps without modifications of parasite loads. BioMed Research International. 2014;2014

40. Chen X, Qiao H, Liu T, Yang Z, Xu L, Xu Y, Ge HM, Tan RX, Li E. Inhibition of herpes simplex virus infection by oligomeric stilbenoids through ROS generation. Antiviral Research. 2012:95(1):30-6.

41. Li Y, Xu Q, Zhang T, Gao M, Wang Q, Han Z, Shao Y, Ma D, Liu S. Host avian beta-defensin and toll-like receptor responses of pigeons following infection with pigeon paramyxovirus type 1. Applied and Environmental Microbiology. 2015;81(18):6415-24

42. Mahajan P, Gnana Oli R, Jachak SM, Bharate SB, Chaudhuri B. Antioxidant and antiproliferative activity of indigocarpan, a pterocarpan from Indigofera aspalathoides. Journal of Pharmacy and Pharmacology. 2016:68(10):1331-9.
43. Wang FY, Su M, Zheng YQ, Wang XG, Kang N, Chen T, Zhu EL, Bian ZX, Tang $X D$. Herbal prescription Chang'an II repairs intestinal mucosal barrier in rats with post-inflammation irritable bowel syndrome. Acta Pharmacologica Sinica. 2015;36(6):708-15

44. Rodrigues MM, Boscardin SB, Vasconcelos JR, Hiyane MI, Salay G, Soares IS. Importance of CD8 T cell-mediated immune response during intracellular parasitic infections and its implications for the development of effective vaccines. Anais da Academia Brasileira de Ciencias. 2003;75(4):443-68.

45. Neff KS, Richards SM, Williams JM, Garman RD, Ruzek MC. Murine antithymocyte globulin T-cell depletion is mediated predominantly by macrophages, but the Fas/FasL pathway selectively targets regulatory T cells. Transplantation. 2011;92(5):523-8.

46. Aly HF, Abd-Alla HI, Ali SA, Alez RA, Abu-Krisha MO, Mamdouh MM Bioinformatics: inflammatory cytokines and attenuation of diabetes hypercholesterolemia-induced renal injury using morning glory and necklace pod extracts. Asian Journal of Pharmaceutical and Clinical Research. 10 (11) 347-55.

47. Foti MC, Amorati R. Non-phenolic radical-trapping antioxidants. Journal of Pharmacy and Pharmacology. 2009;61(11):1435-48.

48. Meir S, Kanner J, Akiri B, Philosoph-Hadas S. Determination and involvement of aqueous reducing compounds in oxidative defense systems of various senescing leaves. Journal of Agricultural and Food Chemistry. 1995;43(7):1813-9

49. Magalingam KB, Radhakrishnan A, Haleagrahara N. Protective effects of quercetin glycosides, rutin, and isoquercetrin against 6-hydroxydopamine (6-OHDA)-induced neurotoxicity in rat pheochromocytoma (PC-12) cells. International Journal of Immunopathology and Pharmacology. 2016;29(1):30-9.

50. Valentová K, Šíma P, Rybková Z, Křížan J, Malachová K, Křen V. (Anti) mutagenic and immunomodulatory properties of quercetin glycosides. Journal of the Science of Food and Agriculture. 2016;96(5):1492-9.

51. Namgoong SY, Lee CH, Kim HP. Effects of isoflavonoids on mouse lymphocyte proliferation in vitro. Archives of Pharmacal Research. 1994;17(4):236-9.

52. Singh N, Tailang M, Mehta SC. A review on herbal plants as immunomodulators International Journal of Pharmaceutical Sciences and Research. 2016;7(9):3602.

53. Chu CY. Anti-lymphoma and immunomodulatory functions of the aqueous extract of Sophora tonkinensis in mice. Hungkuang Journal. 2009;56:98-107.

54. Maghraby AS, Shalaby N, Abd-Alla HI, Ahmed SA, Khaled HM, Bahgat MM Immunostimulatory effects of extract of Pulicaria crispa before and after Schistosoma mansoni infection. Acta Poloniae Pharmaceutica- Drug Research. 2010;67(1):75-9.

55. Abd-Alla HI, Shaaban M, Shaaban KA, Abu-Gabal NS, Shalaby NM, Laatsch H. New bioactive compounds from Aloe hijazensis. Natural Product Research. 2009;23(11):1035-49.

56. Taie HA, Abd-Alla HI, Ali SA, Aly HF. Chemical composition and biological activities of two Solanum tuberosum cultivars grown in Egypt. International Journal of Pharmacy and Pharmaceutical Sciences. 2015;7(6):311-20. 


\section{GRAPHICAL ABSTRACT}

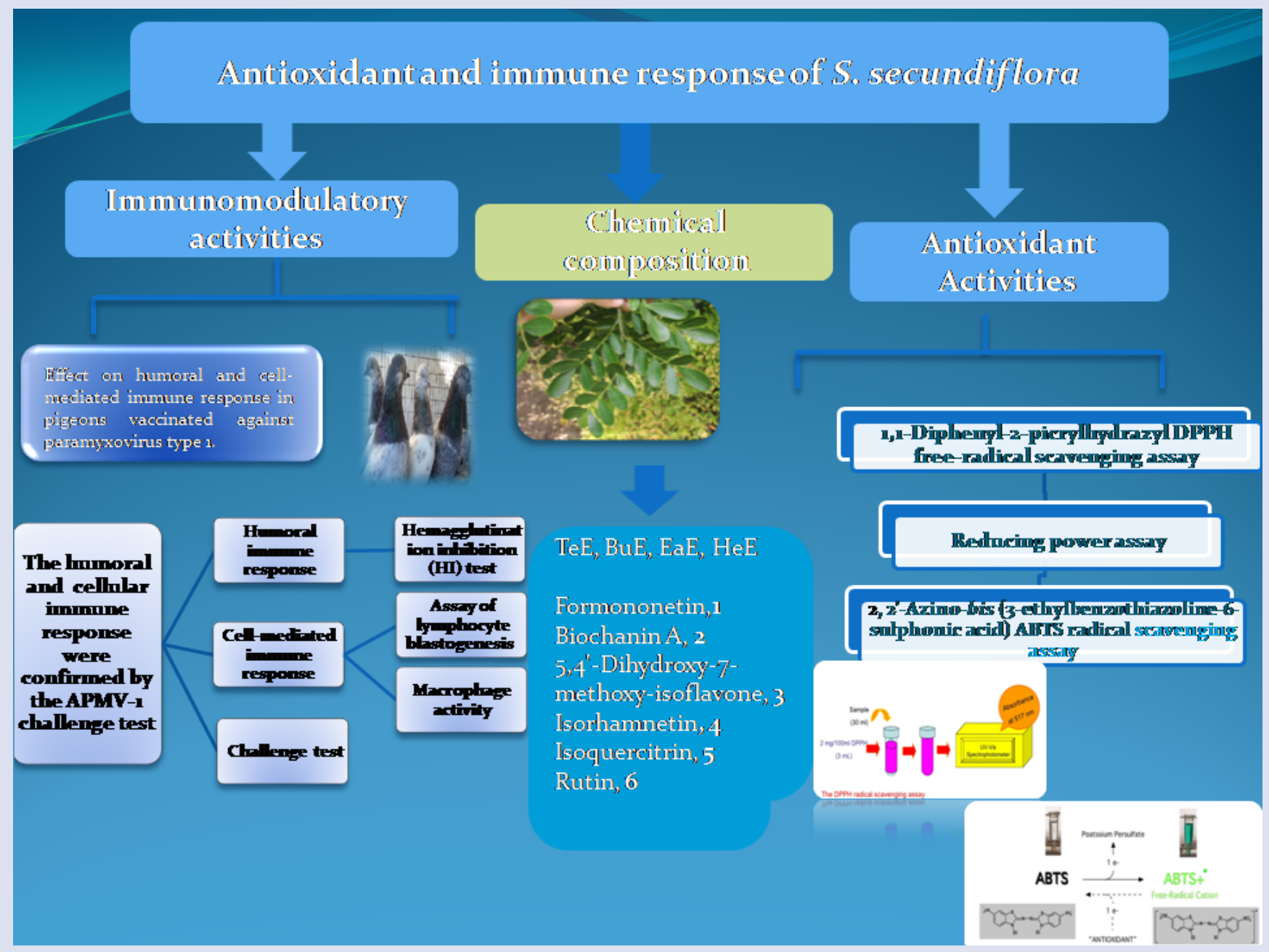

\section{ABOUT AUTHORS}

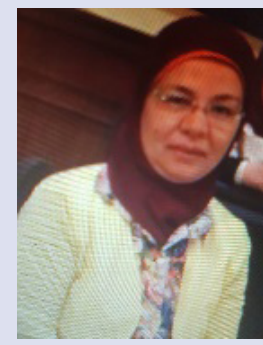

Howaida Ibrahim Abd-Alla has got her PhD in Pharmaceutical Sciences, Cairo Univ., Fac. Pharmacy (2004). She has over 70 publications in peer reviewed journals and attended different international conferences in drug delivery and technology field. Prof. Abd-Alla has got a postdoctoral research grant funded from the Institut Francais d'Egypte in Univ. de Toulouse, France. She upgraded to professor since August, 2014 to date. Currently, she works as a head of Chemistry of Natural Compounds Department. She obtained many local prizes and the Scientific Excellence Prize of King Abdul-Aziz University, KSA. Research Interests of her focuses primarily on isolation and identification of natural compounds from medicinal plants, bacteria and marine organisms using high technique, synthesis of derivatives of natural products, and bioactive assay against different diseases.

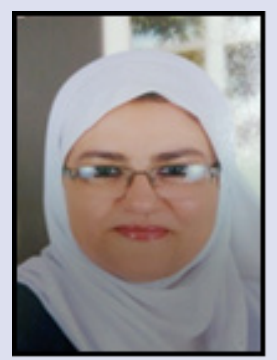

Magda Tohamy Ibrahim is professor and head of Pharmacognosy Department, Faculty of Pharmacy, Sinai University, Kantara Branch. She served for nearly 11 years as head of Pharmacognosy Department, Faculty of Pharmacy, Al-Azhar University since 2008 till 2019. The major focus of her current research is including characterization and structure elucidation of isolated phytoconstituents from medicinal plants and marine algae using advanced spectroscopic techniques, evaluation of their biological activities as well as micropropagation and transplantation of some important species which have been exposed to extinction and therefore preservation techniques are necessary to safeguard their future. 


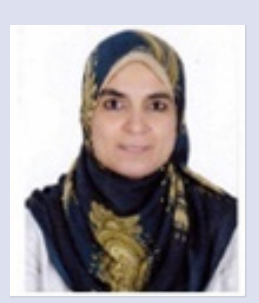

Hanan Anwar Aly Taie is a research professor of Plant Biochemistry - Plant Biochemistry Department, National Research Centre. She has awarded M.Sc. in biochemistry from Cairo University in 1999, and awarded Ph.D. in biochemistry from the same university in 2005. She is a reviewer in many international journals and supervised several M. Sc. and Ph.D. theses.

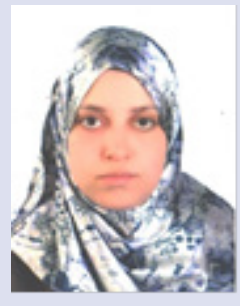

Marwa Abas Hasan is a pharmacist and has got her master degree in Pharmaceutical Sciences, Al-Azhar University, Faculty of Pharmacy (2017). Dr. Mostafa has a research experience focuses on isolation of flavonoids, terpenes, coumarins and polysaccharides from medicinal plants using high techniques for the identification of natural compounds such as 1D and 2D NMR analysis. Also, biological evaluation of natural products such as plant extracts and compounds.

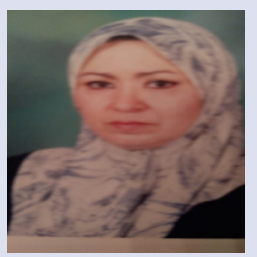

Nagwa Mohamed Mustafa Shalaby is an emeritus professor of chemistry of natural products, Chemistry of Natural Compounds Department, Pharmaceutical and Drug Industries Research Division, National Research Centre. She has got her PhD in organic chemistry, Cairo Univ., Faculty of Sciences (1987). She is a reviewer in many international journals and supervised several M. Sc. and Ph.D. theses.

Cite this article: Abd-Alla HI, Ibrahim MT, Taie HAA, Hasan MA, Shalaby NMM. Antioxidant and the Efficacy of Sophora secundiflora and Methoxyisoflavones in the Immune Function of Pigeons Vaccinated against Paramyxovirus Serotype-1. Pharmacogn J. 2020;12(6):1276-88. 